\title{
Development of surrogate correlation models to predict trace organic contaminant oxidation and microbial inactivation during ozonation
}

\author{
Daniel Gerrity ${ }^{a, b, c, *}$, Sujanie Gamage ${ }^{c}$, Darryl Jones ${ }^{d}$, Gregory V. Korshin ${ }^{e}$, Yunho Lee ${ }^{f, g}$, \\ Aleksey Pisarenko ${ }^{c}$, Rebecca A. Trenholm ${ }^{c}$, Urs von Gunten ${ }^{g, h}$, Eric C. Wert ${ }^{c}$, \\ Shane A. Snyder ${ }^{d}$ \\ a Department of Civil and Environmental Engineering and Construction, University of Nevada, Las Vegas, Box 454015, 4505 S. Maryland \\ Parkway, Las Vegas, NV 89154-4015, United States \\ ${ }^{\mathrm{b}}$ Trussell Technologies, Inc., 232 North Lake Avenue, Suite 300, Pasadena, CA 91101, United States \\ ${ }^{c}$ Applied Research and Development Center, Southern Nevada Water Authority, River Mountain Water Treatment Facility, P.O. Box 99954, \\ Las Vegas, NV 89193-9954, United States \\ ${ }^{\mathrm{d}}$ Department of Chemical and Environmental Engineering, University of Arizona, 1133 E. James E. Rogers Way, Harshbarger 108, Tucson, \\ AZ 85721-0011, United States \\ ${ }^{\mathrm{e}}$ Civil \& Environmental Engineering, University of Washington, 201 More Hall, Box 352700, Seattle, WA 98195-2700, United States \\ ${ }^{\mathrm{f}}$ School of Environmental Science and Engineering, Gwangju Institute of Science and Technology (GIST), 123, Oryong-dong, Buk-gu, \\ Gwangju 500-712, Republic of Korea \\ ${ }^{g}$ Eawag, Swiss Federal Institute of Aquatic Science and Technology, Ueberlandstrasse 133, P.O. Box 611, 8600 Duebendorf, Switzerland \\ ${ }^{\mathrm{h}}$ School of Architecture, Civil, and Environmental Engineering (ENAC), Ecole Polytechnique Federale de Lausanne, CH-1015 Lausanne, \\ Switzerland
}

\section{A R T I C L E I N F O}

Article history:

Received 2 May 2012

Received in revised form

21 August 2012

Accepted 24 August 2012

Available online 13 September 2012

\begin{abstract}
A B S T R A C T
The performance of ozonation in wastewater depends on water quality and the ability to form hydroxyl radicals $(\cdot \mathrm{OH})$ to meet disinfection or contaminant transformation objectives. Since there are no on-line methods to assess ozone and $\bullet \mathrm{OH}$ exposure in wastewater, many agencies are now embracing indicator frameworks and surrogate monitoring for regulatory compliance. Two of the most promising surrogate parameters for ozone-based treatment of secondary and tertiary wastewater effluents are differential $\mathrm{UV}_{254}$ absorbance
\end{abstract}

\footnotetext{
Abbreviations: AFU, arbitrary fluorescence unit; AOP, advanced oxidation process; AWWTP, Australian (anonymous) Wastewater Treatment Plant; BAC, biological activated carbon; BDF, buffered demand free; CCWRD, Clark County Water Reclamation District; CDPH, California Department of Public Health; CFU, colony forming unit; CLV, City of Las Vegas; CT, concentration $\times$ time (as in disinfection); DEET, N,N-diethyl-meta-toluamide; EDC, endocrine disrupting compound; EEM, excitation-emission matrix; EfOM, effluent organic matter; FAT, full advanced treatment; GCGA, Gwinnett County Georgia; GC-MS, gas chromatography mass spectrometry; IPR, indirect potable reuse; KOWWTP, Kloten-Opfikon Wastewater Treatment Plant; LC-MS, liquid chromatography mass spectrometry; LWWTP, Lausanne Wastewater Treatment Plant; MBR, membrane bioreactor; MPN, most probable number; MRL, method reporting limit; MWRDGC, Metropolitan Water Reclamation District of Greater Chicago; pCBA, para-chlorobenzoic acid; IPR, indirect potable reuse; PCU, Pinellas County Utilities; PEG, polyethylene glycol; PFU, plaque forming unit; PPCPs, pharmaceuticals and personal care products; RWWTP, Regensdorf (Wüeri) Wastewater Treatment Plant; TCEP, tris-(2-chloroethyl)-phosphate; TF, total fluorescence; TOC, total organic carbon; TOrCs, trace organic contaminants; TSA, tryptic soy agar; TSB, tryptic soy broth; U.S., United States; UV, ultraviolet; WBMWD, West Basin Municipal Water District.

* Corresponding author. Department of Civil and Environmental Engineering and Construction, University of Nevada, Las Vegas, Box 454015, 4505 S. Maryland Parkway, Las Vegas, NV 89154-4015, United States. Tel.: +1 (702) 895 3955; fax: +1 (702) 8953936.
}

E-mail address: daniel.gerrity@unlv.edu (D. Gerrity). 0043-1354/\$ - see front matter @ 2012 Elsevier Ltd. All rights reserved. http://dx.doi.org/10.1016/j.watres.2012.08.037 
Keywords:

Advanced oxidation process (AOP)

Indirect potable reuse (IPR)

Ozone

Trace organic contaminant (TOrC)

Pharmaceutical

UV absorbance

Fluorescence

Disinfection

Indicator
$\left(\Delta \mathrm{UV}_{254}\right)$ and total fluorescence $(\Delta \mathrm{TF})$. In the current study, empirical correlations for $\Delta \mathrm{UV}_{254}$ and $\Delta \mathrm{TF}$ were developed for the oxidation of 18 trace organic contaminants (TOrCs), including 1,4-dioxane, atenolol, atrazine, bisphenol A, carbamazepine, diclofenac, gemfibrozil, ibuprofen, meprobamate, naproxen, N,N-diethyl-meta-toluamide (DEET), parachlorobenzoic acid (pCBA), phenytoin, primidone, sulfamethoxazole, triclosan, trimethoprim, and tris-(2-chloroethyl)-phosphate (TCEP) $\left(R^{2}=0.50-0.83\right)$ and the inactivation of three microbial surrogates, including Escherichia coli, MS2, and Bacillus subtilis spores $\left(R^{2}=0.46-0.78\right)$. Nine wastewaters were tested in laboratory systems, and eight wastewaters were evaluated at pilot- and full-scale. A predictive model for $\cdot \mathrm{OH}$ exposure based on $\Delta \mathrm{UV}_{254}$ or $\Delta \mathrm{TF}$ was also proposed.

(c) 2012 Elsevier Ltd. All rights reserved.

\section{Introduction}

Trace organic contaminants (TOrCs) pose a challenge for wastewater treatment facilities due to an increased awareness of their ubiquity, the ambiguity of public and aquatic health implications, the high costs associated with their quantification, and the paucity of regulatory guidance. The use of ozone for the transformation of TOrCs, including pharmaceuticals and personal care products (PPCPs) and endocrine disrupting compounds (EDCs), has been studied extensively in the literature (Huber et al., 2003, 2004; Buffle et al., 2006; Lee et al., 2008; Dodd et al., 2009; von Sonntag and von Gunten, 2012). Studies specifically addressing the efficacy of ozone for TOrC elimination, reductions in estrogenicity, and the effects on toxicity have also been performed in pilot- and full-scale systems (Huber et al., 2005; Hollender et al., 2009; Wert et al., 2009a; Stalter et al., 2010a, 2010b; Gerrity et al., 2011a; Gerrity and Snyder, 2011; Zimmermann et al., 2011). Ozone is also effective for the inactivation of a wide range of microbial indicators and pathogens (Driedger et al., 2001; Burns et al., 2007; Gerrity et al., 2011a).

This demonstrated efficacy for TOrC mitigation and disinfection has established ozone as a viable option for wastewater treatment. Ozone-based treatment trains are also becoming increasingly popular in indirect potable reuse (IPR) applications as an alternative to membrane filtration, reverse osmosis, and $\mathrm{UV} / \mathrm{H}_{2} \mathrm{O}_{2}$, which is described as full advanced treatment (FAT) by the California Department of Public Health (CDPH) in the United States (U.S.) (CDPH, 2011). By combining ozone with downstream biological filtration, this alternative treatment train is capable of providing a finished water quality similar to that of FAT, albeit at potentially reduced costs (Hollender et al., 2009; Reungoat et al., 2010; Stalter et al., 2010a, 2010b; Gerrity et al., 2011a; Reungoat et al., 2012; Zimmermann et al., 2011).

In wastewater applications, particularly when supplemented with hydrogen peroxide, ozonation can be considered an advanced oxidation process (AOP) due to its rapid decomposition into hydroxyl radicals $(\cdot \mathrm{OH})$. In contrast with drinking water applications (Kaiser et al., submitted for publication), there are no on-line methods to measure ozone and $\cdot \mathrm{OH}$ exposure in wastewater so the "CT" approach typically associated with chlorine disinfection (i.e., the product of oxidant concentration and time) cannot be applied to estimate treatment performance. Also, frequent monitoring for TOrCs and pathogens is a costly and time-consuming proposition. As a result, many agencies are embracing indicator frameworks and highlighting the need for surrogate monitoring (Dickenson et al., 2009). For example, CDPH recently published a revised set of draft regulations for groundwater replenishment, which outlines required removals for indicator compounds based on their chemical structures and functional groups (e.g., hydroxyl aromatic, saturated aliphatic). Although these specified removals apply only to advanced oxidation in FAT applications (i.e., reverse osmosis permeate), the framework can be applied more broadly as a TOrC mitigation baseline. In addition to the specified removals, CDPH also requires FAT facilities to identify at least one surrogate parameter that can be monitored continuously, predict the level of oxidation for the indicator compounds, and alert operators to process inefficiencies and failures. Several common water quality parameters associated with bulk organic matter, specifically differential UV absorbance ( $\Delta U V$ ) and total fluorescence $(\Delta \mathrm{TF})$, offer particularly promising solutions for this type of application.

Currently, there are few studies that describe the relationships between changes in bulk organic matter, contaminant destruction, and microbial inactivation. Studies using fluorescence as part of an analytical method to detect TOrCs are becoming more common (Camacho-Munoz et al., 2009), but the goal of these studies is inherently different than using changes in bulk organic matter to estimate oxidation efficacy. Although the high sensitivity of fluorometers offers a promising tool for detection of individual contaminants, this method is hindered by interferences from background effluent organic matter (EfOM) in wastewater applications (Fig. S1). Therefore, $\Delta U V$-more specifically, $\Delta U_{254}$-and $\Delta \mathrm{TF}$ currently offer the most promising tools to supplement existing analytical methods based on liquid or gas chromatography and mass spectrometry (LC-MS or GC-MS).

Buffle et al. (2006) proposed the use of $\Delta U V$ to determine ozone exposure in wastewater applications after observing a first-order kinetic relationship between the two parameters. Based on this concept, Bahr et al. (2007), Wert et al. (2009b), and Nanaboina and Korshin (2010) developed preliminary correlations between $\Delta U_{254}$ and several indicator compounds and microbes. Bahr et al. (2007) presented the linear regression parameters in relation to second-order ozone and $\cdot \mathrm{OH}$ rate constants. Wert et al. (2009b) indicated that ozone-susceptible target compounds (i.e., $k_{\mathrm{O}_{3}}>10^{3} \mathrm{M}^{-1} \mathrm{~s}^{-1}$ ) demonstrated strong 
linear correlations with 0-50\% reductions in $\mathrm{UV}_{254}$ absorbance, whereas slower-reacting compounds (i.e., $k_{\mathrm{O}_{3}}<10^{3} \mathrm{M}^{-1} \mathrm{~s}^{-1}$ ) correlated well with $15-65 \%$ reductions in $\mathrm{UV}_{254}$ absorbance. In addition to developing individual correlations for six pharmaceuticals, the study indicated that the empirical correlations were consistent between different wastewater qualities. Rosario-Ortiz et al. (2010) extended this concept to the $\mathrm{UV} / \mathrm{H}_{2} \mathrm{O}_{2}$ advanced oxidation process and confirmed that these correlations were also consistent between different water qualities. These preliminary studies indicate that $\Delta \mathrm{UV}_{254}$ correlations offer powerful, robust, and straightforward tools that can easily be incorporated into full-scale applications.

Several studies have expanded on this preliminary research to incorporate both commercially available and innovative technologies. Pisarenko et al. (2012) developed a set of TOrC correlations based on $\Delta \mathrm{UV}_{254}$ and $\Delta \mathrm{TF}$ using a pilotscale $\mathrm{O}_{3} / \mathrm{H}_{2} \mathrm{O}_{2}$ reactor (HiPOx ${ }^{\circledR}$, APTwater, Long Beach, CA), while Gerrity et al. (2010) illustrated how the $\Delta U^{254}$ correlation concept can be applied to novel forms of advanced oxidation, specifically nonthermal plasma (AquaPure, PetachTikva, Israel). Therefore, the existing literature offers the following conclusions: (1) $\Delta U V$ and $\Delta T F$ are strongly correlated with the elimination of aromatic and non-aromatic TOrCs, (2) each compound has a unique set of regression parameters related to its second-order rate constants for reactions with various oxidants, (3) unit processes with different oxidation mechanisms (e.g., ozone/ $\mathrm{H}_{2} \mathrm{O}_{2}$ vs. $\mathrm{UV} / \mathrm{H}_{2} \mathrm{O}_{2}$ ) also have unique sets of correlations, and (4) the correlations for specific contaminants and oxidation processes are consistent between different secondary or tertiary effluents.

The objective of the current study was to expand on this foundation by developing a more comprehensive database of bench-scale correlations (i.e., increase the number of contaminants and matrices), validating those same correlations at pilot- and full-scale, and illustrating how the concept can be integrated into an actual treatment train to provide real-time, on-line monitoring of process performance. This study incorporated 18 trace organic contaminants, three microbial surrogates, nine sets of bench-scale experiments, four independent pilot-scale validations, and one full-scale validation. A commercially available on-line UV absorbance analyzer was also integrated into the study. Ultimately, this database can be integrated into the software of emerging absorbance and fluorescence technologies to allow for optimization of dosing conditions and to provide real-time estimates of contaminant oxidation and disinfection.

\section{Materials and methods}

\subsection{Bench-scale experiments}

Unfiltered secondary effluent was collected from nine wastewater treatment facilities, as described in Table 1. For the five wastewaters from the U.S., a portion of the secondary effluent was filtered in series through $10-\mu \mathrm{m}$ and $0.5-\mu \mathrm{m}$ (nominal) polypropylene spiral-wound cartridge filters (MicroSentry ${ }^{\mathrm{TM}}$, Shelco Filters, Middletown, CT). The four remaining wastewaters were filtered in the laboratory with $0.45-\mu \mathrm{m}$ cellulose acetate filters. Differences in oxidation efficacy for unfiltered versus filtered secondary effluents were evaluated during the bench-scale phase. Each matrix was analyzed for a variety of general water quality parameters (Table 1 ) to characterize the matrices and determine the appropriate ozone and $\mathrm{H}_{2} \mathrm{O}_{2}$ dosing conditions.

Table 1 - Summary of average water quality data for the bench- (filtered), pilot-, and full-scale experiments.

\begin{tabular}{|c|c|c|c|c|c|c|c|c|c|}
\hline Sample ID & Location & $\mathrm{pH}$ & $\begin{array}{l}\text { TOC } \\
\mathrm{mg} / \mathrm{L}\end{array}$ & $\begin{array}{l}\mathrm{UV}_{254} \\
\mathrm{~cm}^{-1}\end{array}$ & $\begin{array}{c}\mathrm{TF} \\
\mathrm{AFU}\end{array}$ & $\begin{array}{c}\text { Alkalinity } \\
\mathrm{mg} / \mathrm{L} \text { as } \mathrm{CaCO}_{3}\end{array}$ & $\begin{array}{c}\mathrm{NH}_{3} \\
\mathrm{mg}-\mathrm{N} / \mathrm{L}\end{array}$ & $\begin{array}{c}\mathrm{NO}_{3} \\
\mathrm{mg}-\mathrm{N} / \mathrm{L}\end{array}$ & $\begin{array}{c}\mathrm{NO}_{2} \\
\mathrm{mg}-\mathrm{N} / \mathrm{L}\end{array}$ \\
\hline \multicolumn{10}{|c|}{ Secondary effluents for bench-scale experiments (after laboratory filtration) } \\
\hline CCWRD & Nevada & 6.9 & 7.6 & 0.146 & 38,874 & 123 & 0.09 & 14.0 & 0.06 \\
\hline MWRDGC & Illinois & 7.6 & 6.9 & 0.131 & 37,712 & 134 & 0.07 & 9.10 & $<0.05$ \\
\hline WBMWD & California & 7.3 & 18.0 & 0.268 & 94,807 & 332 & 46.9 & 0.11 & 0.17 \\
\hline PCU & Florida & 7.3 & 7.2 & 0.187 & 53,996 & 205 & 0.02 & 7.70 & $<0.05$ \\
\hline GCGA & Georgia & 7.3 & 6.3 & 0.130 & 34,795 & 169 & 5.80 & 8.60 & 0.30 \\
\hline LWWTP & Switzerland & 7.2 & 6.0 & 0.099 & 27,238 & 65 & 0.11 & 24.0 & 0.16 \\
\hline RWWTP & Switzerland & 7.2 & 4.7 & 0.129 & N/A & 220 & 0.03 & 12.0 & 0.01 \\
\hline KOWWTP & Switzerland & 7.0 & 4.7 & 0.110 & N/A & 145 & 0.02 & 13.2 & 0.07 \\
\hline AWWTP & Australia & 7.2 & 7.0 & 0.201 & 51,642 & 105 & 0.09 & 18.0 & 0.05 \\
\hline \multicolumn{10}{|c|}{ Tertiary effluents for pilot-scale experiments } \\
\hline Lit. $1^{\mathrm{a}}$ & Nevada & 8.2 & 6.6 & 0.140 & N/A & 128 & $<0.20$ & 13.0 & $<0.05$ \\
\hline Lit. $2^{a}$ & Florida & 7.6 & 10.3 & 0.260 & N/A & 269 & 6.98 & 0.07 & 0.77 \\
\hline Lit. $3^{a}$ & Colorado & 7.1 & 10.3 & 0.171 & N/A & 101 & 1.28 & 9.70 & 0.40 \\
\hline Reno $1^{\mathrm{b}}$ & Nevada & 6.9 & 5.9 & 0.120 & 32,608 & 90 & N/A & N/A & $<0.05$ \\
\hline Reno $2^{\mathrm{b}}$ & Nevada & 6.9 & 6.6 & 0.140 & 31,505 & 90 & N/A & N/A & $<0.05$ \\
\hline Tucson & Arizona & N/A & 5.6 & 0.157 & 46,496 & N/A & N/A & N/A & N/A \\
\hline $\mathrm{CLV}^{\mathrm{c}}$ & Nevada & 7.3 & 6.0 & 0.130 & 26,988 & 99 & $<0.50$ & 13.8 & $<0.10$ \\
\hline \multicolumn{10}{|c|}{ Tertiary effluent for full-scale sampling } \\
\hline Springfield & Missouri & 7.9 & 4.9 & 0.116 & 28,782 & $\mathrm{~N} / \mathrm{A}$ & $<0.10$ & 11.0 & N/A \\
\hline
\end{tabular}


Separate oxidation experiments were performed for each of the major tests, as listed below, to provide sufficient sample volume for the analytical methods and to reduce potential interferences caused by spiked contaminants. Separate secondary effluent samples were spiked with (1) approximately $1 \mu \mathrm{g} / \mathrm{L}$ of each of the target TOrCs (3.4-5.2 nM), (2) $500 \mu \mathrm{g} / \mathrm{L}$ of para-chlorobenzoic acid (pCBA; $3.2 \mu \mathrm{M})$, (3) $1 \mathrm{mg} / \mathrm{L}$ of 1,4-dioxane $(11 \mu \mathrm{M})$, (4) $10^{7} \mathrm{MPN} / 100 \mathrm{~mL}$ of Escherichia coli 15597 (ATCC 15597), (5) $10^{7} \mathrm{PFU} / \mathrm{mL}$ of the bacteriophage MS2 (ATCC 15597-B1), and (6) $10^{5} \mathrm{CFU} / 100 \mathrm{~mL}$ of Bacillus subtilis spores (ATCC 23059). The E. coli, MS2, and B. subtilis spore assays were only performed on six of the nine matrices.

Bench-scale ozone tests were performed by spiking aliquots of ozone stock from a batch reactor. Nanopure water (Barnstead, Dubuque, IA) was placed inside a water-jacketed flask and cooled to $2{ }^{\circ} \mathrm{C}$. Once cooled, $11 \%$ gaseous ozone was diffused into the water using oxygen-fed generators (U.S. experiments: model CFS-1A, Ozonia North America, Inc., Elmwood Park, NJ; international experiments: model CMG 3-3, Innovatec, Rheinbach, Germany). This configuration resulted in ozone stock solution concentrations ranging from 70 to $110 \mathrm{mg} / \mathrm{L}$, which were measured with the indigo trisulfonate colorimetric method according to Standard Method 4500-O3 or by direct photometry at $258 \mathrm{~nm}$ (Hoigne and Bader, 1994). With the exception of one secondary effluent (GCGA), the study targeted mass-based ozone to total organic carbon $\left(\mathrm{O}_{3}\right.$ :TOC) ratios of $0.25,0.50,1.0$, and 1.5 ( $\mathrm{mg} \mathrm{O}_{3} / \mathrm{mg}$ TOC). Since nitrite consumes dissolved ozone at a 1:1 mass ratio, the high nitrite concentration ( $0.3 \mathrm{mg}-\mathrm{N} / \mathrm{L})$ in the GCGA secondary effluent relative to its TOC $(6.3 \mathrm{mg} / \mathrm{L})$ resulted in corrected $\mathrm{O}_{3}$ :TOC ratios of $0.07,0.32,0.83$, and 1.34 . The effect of $\mathrm{H}_{2} \mathrm{O}_{2}$ addition was also evaluated by targeting molar $\mathrm{H}_{2} \mathrm{O}_{2}: \mathrm{O}_{3}$ ratios of $0,0.5$, and 1.0. For the ozone/ $\mathrm{H}_{2} \mathrm{O}_{2}$ experiments, $\mathrm{H}_{2} \mathrm{O}_{2}$ was added immediately before the addition of the ozone stock solution. All dosing ratios, bulk organic characterization, and target compound concentrations accounted for the dilution effect of the ozone spike. Upon completion of ozone decay $\left(\mathrm{O}_{3}<0.03 \mathrm{mg} / \mathrm{L}\right)$, the samples were quenched with $10 \mathrm{mg} / \mathrm{L}$ of sodium thiosulfate to eliminate any residual $\mathrm{H}_{2} \mathrm{O}_{2}$, preserved with $1 \mathrm{~g} / \mathrm{L}$ of sodium azide, and stored at $4{ }^{\circ} \mathrm{C}$ prior to analysis.

\subsection{Pilot-scale validation}

The results from the bench-scale experiments were compared with an independent pilot-scale data set from the literature (Wert et al., 2009b) and three pilot-scale reactors associated with the current study. The ozone test matrices were comprised of five different sand-filtered effluents, one ultrafiltration filtrate, and one membrane bioreactor (MBR) filtrate. Validation data are limited for some compounds since the study from the literature only included a subset of the target compound list, and some compounds were not detected in the ambient matrices.

The Wert et al. (2009b) study evaluated pilot-scale ozonation $(1 \mathrm{~L} / \mathrm{min})$ of sand-filtered tertiary effluent from three different locations in the U.S. The ozone doses ranged from 0 to $12 \mathrm{mg} / \mathrm{L}$ (no $\mathrm{H}_{2} \mathrm{O}_{2}$ addition), which corresponded to massbased $\mathrm{O}_{3}$ :TOC ratios ranging from 0 to 1.2. For the current study, a sand-filtered tertiary effluent (Tucson, AZ) was treated with a $40-\mathrm{L} / \mathrm{min}$ pilot-scale ozone/ $\mathrm{UV} / \mathrm{H}_{2} \mathrm{O}_{2}$ reactor
(Wedeco/ITT, Herford, Germany), but it was only operated in the ozone and ozone $/ \mathrm{H}_{2} \mathrm{O}_{2}$ modes for the purposes of this study. The ozone doses ranged from 0 to $9 \mathrm{mg} / \mathrm{L}$, which corresponded to mass-based $\mathrm{O}_{3}$ :TOC ratios of $0-1.5$, and molar $\mathrm{H}_{2} \mathrm{O}_{2}: \mathrm{O}_{3}$ ratios of 0 and 1.0 were also tested.

A $40-\mathrm{L} / \mathrm{min}$ pilot-scale IPR treatment train (Reno, NV) comprised of ozone and biological activated carbon (BAC) was also evaluated for this study. The ozone system (HiPOx ${ }^{\circledR}$, APTwater, Long Beach, CA) was fed with tertiary effluent after ultrafiltration for the first phase of the study and sand-filtered tertiary effluent for the second phase of the study. During both phases, ozone was dosed at $5 \mathrm{mg} / \mathrm{L}$ (mass-based $\mathrm{O}_{3}$ :TOC ratio of 0.8 ), and $\mathrm{H}_{2} \mathrm{O}_{2}$ was dosed at a molar $\mathrm{H}_{2} \mathrm{O}_{2}: \mathrm{O}_{3}$ of 1.0 for bromate mitigation. Additional details related to the treatment train and water quality were described previously in the literature (Gerrity et al., 2011a).

The final pilot-scale system (City of Las Vegas, NV) included an 80-L/min MBR (Hydranautics, Nitto Denko, Oceanside, CA), a $40-\mathrm{L} / \mathrm{min}$ ozone system $\left(\mathrm{HiPOx}^{\circledR}\right)$, and two $40-\mathrm{L} / \mathrm{min}$ reverse osmosis skids operated in parallel (Hydranautics). Ozone doses ranged from 0 to $9 \mathrm{mg} / \mathrm{L}$ (mass-based $\mathrm{O}_{3}$ :TOC ratios of $0-2.0$ ), and molar $\mathrm{H}_{2} \mathrm{O}_{2}: \mathrm{O}_{3}$ ratios ranged from 0 to 0.5 . The ozone process was evaluated with an online absorbance analyzer (spectro::lyser, s::can Messtechnik, Vienna, Austria) that was externally mounted and fed with a sidestream of process flow. Only one analyzer was available so it was adjusted manually to receive MBR filtrate and ozonated MBR filtrate at different times during the monitoring period to evaluate temporal variability. Additional details related to the operation of this pilot have also been described in the literature (Pisarenko et al., 2012).

\subsection{Full-scale validation}

Samples were collected from a full-scale wastewater treatment plant (Springfield, Missouri) with conventional activated sludge, sand filtration, and ozone for final disinfection. During the sampling event, the $1.14 \times 10^{5} \mathrm{~m}^{3} /$ day facility was targeting an ozone production rate of approximately $544 \mathrm{~kg} /$ day. This corresponds to an applied ozone dose of $4.8 \mathrm{mg} / \mathrm{L}$ and a mass-based $\mathrm{O}_{3}$ :TOC ratio of approximately 1.0.

\subsection{Analytical methods}

\subsubsection{Bulk organic matter}

For TOC analysis, samples were collected in glass vials, acidified to $\mathrm{pH}<3$ with hydrochloric acid, and filtered through 0.20-mm hydrophilic polypropylene filters (GHP Acro-disk, Pall Life Sciences) prior to quantification with a Shimadzu (Columbia, MD) TOC analyzer. Absorbance spectra were measured using a PerkinElmer (Waltham, MA) Lambda 45 UV-VIS Spectrometer, consistent with Standard Method 5910 B. Excitation-emission matrices (EEMs) were created using a QuantaMaster UV-Vis QM4 Steady State Spectrofluorometer (Photon Technology International, Inc., Birmingham, NJ). The spectrofluorometer included a $75-\mathrm{W}$, short-arc xenon lamp with an excitation range from 240 to $1200 \mathrm{~nm}$. Data processing in MATLAB (Natick, MA) included corrections for Raman scattering, blank response, the spectral sensitivity of the lamp, and the inner filter effect (i.e., the absorbance of 
the matrix). Regional integration was performed according to published literature (Chen et al., 2003) with slight modifications (Gerrity et al., 2011a) to calculate the regional and total fluorescence intensities (in arbitrary fluorescence units) for each sample.

\subsubsection{Trace organic contaminants}

In addition to pCBA and 1,4-dioxane, the following TOrCs were targeted in this study: atenolol, atrazine, bisphenol A, carbamazepine, N,N-diethyl-meta-toluamide (DEET), diclofenac, gemfibrozil, ibuprofen, meprobamate, musk ketone, naproxen, phenytoin, primidone, sulfamethoxazole, tris-(2chloroethyl)-phosphate (TCEP), triclosan, and trimethoprim. Due to its high volatility, musk ketone was subsequently omitted from the study.
These target compounds were analyzed using a Symbiosis (Spark Holland, Emmen, the Netherlands) automated on-line solid phase extractor and a 4000 QTRAP triple quadrupolelinear ion trap hybrid mass spectrometer (ABSCIEX, Foster City, CA, USA). Full method descriptions and parameters, including acquisition and preparation of the TOrC spike and standard solutions, have been described previously (Trenholm et al., 2009; Gerrity et al., 2011b). The 1,4-dioxane samples were processed and analyzed by Weck Laboratories (Industry, CA) using EPA Methods 3520C and $8270 \mathrm{M}$, respectively. The pCBA samples were analyzed by LC-MS/MS according to previously published methods (Vanderford et al., 2007).

The method reporting limits (MRLs) and second-order ozone and $\cdot \mathrm{OH}$ rate constants for the reactions with these compounds are summarized in Table 2 . The compounds were

\section{Table 2 - Summary of target compounds and rate constants.}

\begin{tabular}{|c|c|c|c|c|}
\hline Compound $^{\mathrm{a}}$ & MRL (ng/L) & $k_{\mathrm{O}_{3}}\left(\mathrm{M}^{-1} \mathrm{~s}^{-1}\right), \mathrm{pH}=7$ & $k \cdot \mathrm{OH}\left(\mathrm{M}^{-1} \mathrm{~s}^{-1}\right)$ & CDPH Classification $^{b}$ \\
\hline \multicolumn{5}{|c|}{ Group 1 - High reactivity with both ozone and $\cdot \mathrm{OH}$} \\
\hline Bisphenol $\mathrm{A}^{\mathrm{h}, \mathrm{i}}$ & 50 & $7 \times 10^{5}$ & $1 \times 10^{10}$ & A. Hydroxy Aromatic \\
\hline Carbamazepine $^{c}$ & 10 & $3 \times 10^{5}$ & $9 \times 10^{9}$ & $\begin{array}{l}\text { C. Nonaromatic with carbon } \\
\text { double bonds }\end{array}$ \\
\hline Diclofenac ${ }^{c}$ & 25 & $1 \times 10^{6}$ & $8 \times 10^{9}$ & D. Deprotonated amine \\
\hline Naproxen $^{\mathrm{d}, \mathrm{s}}$ & 25 & $2 \times 10^{5}$ & $1 \times 10^{10}$ & E. Alkoxy polyaromatic \\
\hline Sulfamethoxazole ${ }^{c}$ & 25 & $3 \times 10^{6}$ & $6 \times 10^{9}$ & B. Amino/acylamino aromatic \\
\hline Triclosan ${ }^{e, j}$ & 25 & $4 \times 10^{7}$ & $1 \times 10^{10}$ & A. Hydroxy aromatic \\
\hline Trimethoprim ${ }^{\mathrm{f}}$ & 10 & $3 \times 10^{5}$ & $7 \times 10^{9}$ & D. Deprotonated amine \\
\hline \multicolumn{5}{|c|}{ Group 2 - Moderate reactivity with ozone and high reactivity with $\cdot \mathrm{OH}$} \\
\hline Atenololg & 25 & $2 \times 10^{3}$ & $8 \times 10^{9}$ & D. Deprotonated amine \\
\hline Gemfibrozil ${ }^{\mathrm{j}, \mathrm{k}}$ & 10 & $5 \times 10^{4}$ & $1 \times 10^{10}$ & F. Alkoxy aromatic \\
\hline \multicolumn{5}{|c|}{ Group 3 - Moderate reactivity with both ozone and $\cdot \mathrm{OH}$} \\
\hline DEET $^{\mathrm{j}, 1}$ & 25 & $<10$ & $5 \times 10^{9}$ & G. Alkyl aromatic \\
\hline Ibuprofen ${ }^{c}$ & 25 & 10 & $7 \times 10^{9}$ & G. Alkyl aromatic \\
\hline $\mathrm{pCBA}^{\mathrm{p}}$ & 10,000 & $<0.1$ & $5 \times 10^{9}$ & G. Alkyl aromatic \\
\hline Phenytoin ${ }^{\mathrm{j}, \mathrm{m}}$ & 10 & $<10$ & $6 \times 10^{9}$ & G. Alkyl aromatic \\
\hline Primidone $e^{r, j}$ & 10 & 1 & $7 \times 10^{9}$ & G. Alkyl aromatic \\
\hline \multicolumn{5}{|c|}{ Group 4 - Low reactivity with ozone and moderate reactivity with $\cdot \mathrm{OH}$} \\
\hline 1,4-Dioxane ${ }^{q}$ & 500 & $<1$ & $3 \times 10^{9}$ & $\begin{array}{l}\text { Alternative criterion } \\
\text { (0.5-log removal) }\end{array}$ \\
\hline Atrazine $^{\mathrm{n}}$ & 10 & 6 & $3 \times 10^{9}$ & D. Deprotonated amine \\
\hline Meprobamate ${ }^{j}$ & 10 & $<1$ & $4 \times 10^{9}$ & H. Saturated aliphatic \\
\hline \multicolumn{5}{|c|}{ Group 5 - Low reactivity with both ozone and $\cdot \mathrm{OH}$} \\
\hline Musk Ketone ${ }^{j}$ & 100 & $<1$ & $2 \times 10^{8}$ & I. Nitro aromatic \\
\hline TCEP & 200 & $<1$ & $6 \times 10^{8}$ & H. Saturated aliphatic \\
\hline
\end{tabular}

a Superscripts refer to sources of $\mathrm{O}_{3}(\mathrm{pH}=7)$ and $\cdot \mathrm{OH}$ rate constants, respectively.

b CDPH, 2011; Groups A-G require 0.5-log removal and Groups H-I require 0.3-log removal.

c Huber et al. (2003).

d Huber et al. (2005).

e Suarez et al. (2007).

f Dodd et al. (2006).

g Benner et al. (2008).

h Deborde et al. (2005).

i Rosenfeldt and Linden (2004).

j Lee and von Gunten (2012)

k Razavi et al. (2009).

1 Song et al. (2009).

$m$ Yuan et al. (2009).

n Acero et al. (2000).

o Watts and Linden (2009).

p Katsoyiannis et al. (2011).

q Bowman et al. (2001).

$r$ Real et al. (2009).

s Packer et al. (2003). 
divided into five groups according to their relative reactivity with ozone and $\cdot \mathrm{OH}$, and they were also classified according to the recently revised CDPH Groundwater Replenishment Reuse regulations (CDPH, 2011). For context, the advanced oxidation process in every FAT facility in the State of California must demonstrate 0.5-log (groups A-G) and 0.3-log (groups $\mathrm{H}-\mathrm{I}$ ) removal of at least one indicator compound in each group. Alternatively, the facility may demonstrate 0.5 log removal of 1,4-dioxane in accordance with the previous draft regulations. In the context of this study, the CDPH regulations can generally be achieved by demonstrating 0.5 log removal for groups 1-3 and 0.3-log removal for groups 4-5. It is important to note that this CDPH classification scheme specifically applies to RO permeate, but it is included in this study for oxidation of secondary and tertiary effluents as a treatment baseline.

\subsubsection{Microbial surrogates}

E. coli samples were assayed with the 24-h Colilert (Idexx, Westbrook, ME) method using the Quanti-Tray 2000 quantification protocol. E. coli 15597 spiking stocks were propagated in log phase in tryptic soy broth (TSB). The concentrated stocks were then centrifuged, washed, and resuspended in buffered demand-free (BDF) water (Thurston-Enriquez et al., 2003). The final stocks generally contained $\sim 10^{10} \mathrm{CFU} / 100 \mathrm{~mL}$.
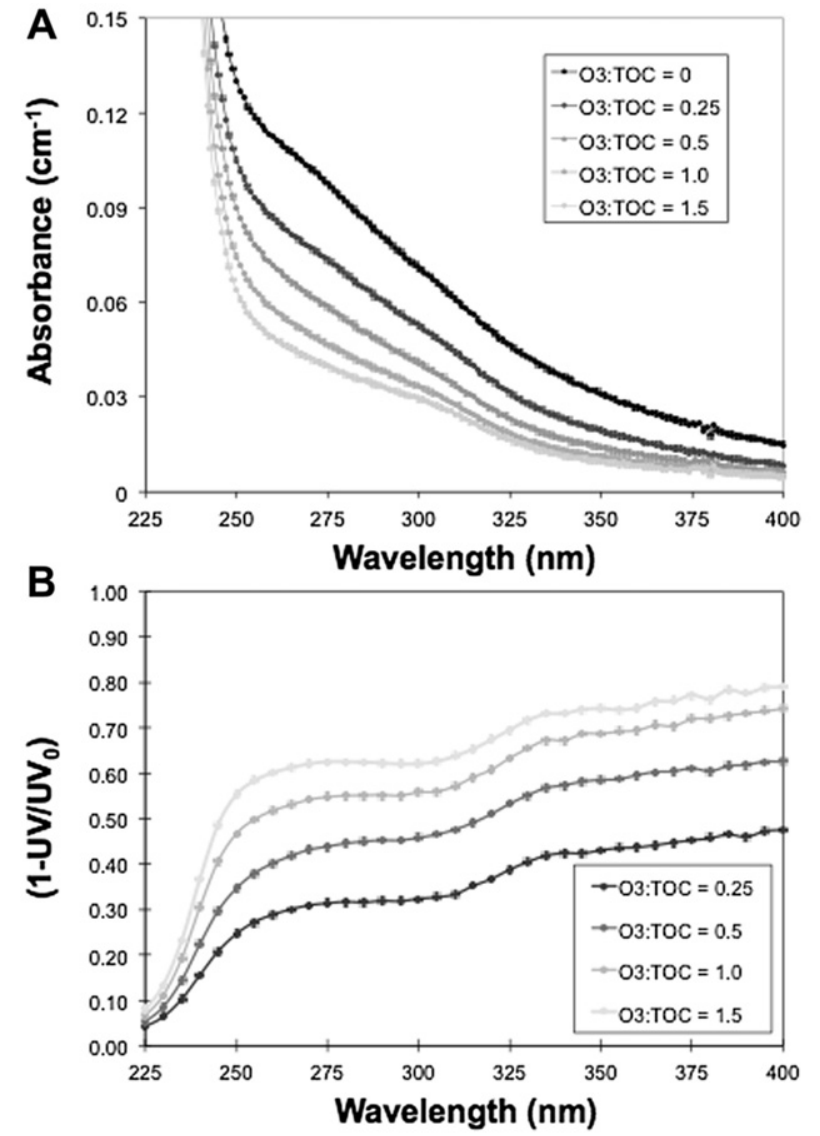

The bacteriophage MS2, which is often used as a surrogate for human enteroviruses, was prepared and assayed with the double agar layer method (Adams, 1959) using antibioticresistant E. coli 700891 (ATCC 700891) as the bacterial host. All MS2 culture media (i.e., TSB, $0.7 \%$ tryptic soy agar (TSA) for the soft overlay, and $1.5 \%$ TSA as the solid substrate) was spiked with ampicillin and streptomycin at final concentrations of $15 \mathrm{mg} / \mathrm{L}$ to prevent growth of indigenous bacteria. Plaques were counted after $18 \mathrm{~h}$ of incubation at $35^{\circ} \mathrm{C}$. MS2 spiking stocks were purified with a polyethylene glycol (PEG) precipitation and Vertrel extraction before being resuspended in BDF water. This purification process was used to monodisperse the bacteriophages and remove a significant portion of the organic matter associated with the culture media, thereby reducing potential scavenging effects during the oxidation experiments (Mesquita et al., 2010). The final stocks generally contained $\sim 10^{11} \mathrm{PFU} / \mathrm{mL}$.

$B$. subtilis spores-a surrogate for ozone-resistant microorganisms-were propagated in TSB at $35^{\circ} \mathrm{C}$ and $150 \mathrm{rpm}$ for $24 \mathrm{~h}$, centrifuged and washed twice in BDF water to remove the nutrient-rich media, and sporulated in BDF water at $35^{\circ} \mathrm{C}$ and $150 \mathrm{rpm}$ for an additional $24 \mathrm{~h}$. The sporulated stock was heat-shocked at $80^{\circ} \mathrm{C}$ and $50 \mathrm{rpm}$ for $12 \mathrm{~min}$ to inactivate any remaining vegetative bacteria. The spore suspension was centrifuged and washed twice in BDF water in order to create
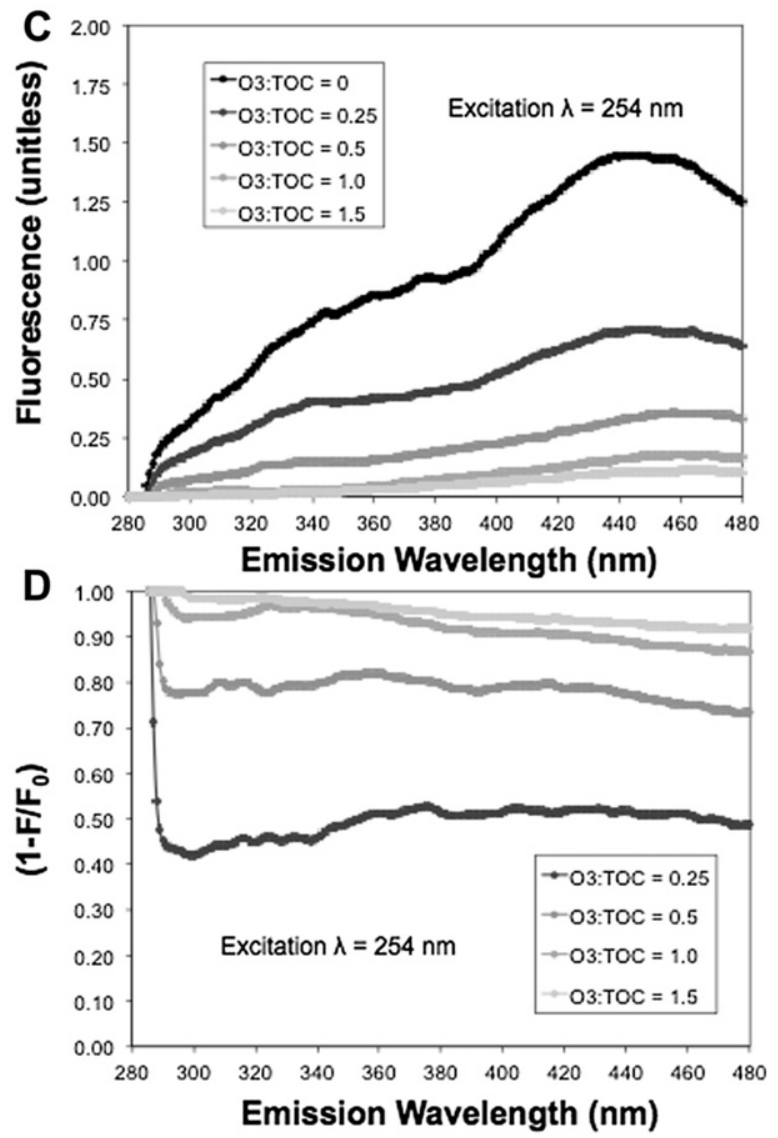

Fig. 1 - Examples of changes in bulk organic matter as a function of ozone dose $\left(\mathrm{O}_{3}: \mathrm{TOC}\right.$ ratio) in CCWRD secondary effluent samples: (A) absorbance spectra, (B) relative differential absorbance spectra, (C) fluorescence spectra (arbitrary fluorescence units) at an excitation wavelength of $254 \mathrm{~nm}$, and (D) relative differential fluorescence spectra at an excitation wavelength of $254 \mathrm{~nm}$. 
the final spiking stock. The final stocks generally contained $\sim 10^{8} \mathrm{CFU} / 100 \mathrm{~mL}$ in the sporulated form. All spore samples were heat-shocked at $80^{\circ} \mathrm{C}\left( \pm 5^{\circ} \mathrm{C}\right)$ and $50 \mathrm{rpm}$ for $12 \mathrm{~min}$ prior to plating. Samples with higher anticipated concentrations of spores (i.e., $>20 / \mathrm{mL}$ ) were assayed with the pour plate method using molten nutrient agar (1\%) supplemented with trypan blue. Lower concentrations of spores were assayed with membrane filtration using $0.45-\mu \mathrm{m}$ filters and nutrient agar plates supplemented with trypan blue. Plates were counted after $24 \mathrm{~h}$ of incubation at $35^{\circ} \mathrm{C}$.

\section{Results and discussion}

\subsection{Selection of surrogate parameters}

Analysis of the full absorbance spectra for each sample indicated that ozone and ozone $/ \mathrm{H}_{2} \mathrm{O}_{2}$ resulted in prominent and monotonic decreases in absorbance at all wavelengths. An example is provided for CCWRD in Fig. 1A. These decreases were also highly reproducible with other secondary effluents. The maximum differentials occurred at wavelengths between 250 and $270 \mathrm{~nm}$, and the relative differentials (Fig. 1B; i.e., $\Delta \mathrm{UV}$ ) offered easily decipherable plateaus between 250 and $300 \mathrm{~nm}$. With respect to fluorescence, all major constituents of EfOM (i.e., microbial biopolymers, fulvic-like, and humic-like species) experienced significant reductions in fluorescence, although the rates of transformation differed between the major groups (data not shown). The fluorescence spectra at an excitation wavelength of $254 \mathrm{~nm}$ for ozonated CCWRD samples are illustrated in Fig. 1C, and the corresponding relative differential fluorescence spectra (i.e., $\Delta \mathrm{TF}$ ) are illustrated in Fig. 1D. These observations confirm that changes in absorbance and fluorescence reflect the behavior of the entire ensemble of compounds comprising EfOM. Furthermore, these observations support the conclusion that treatment efficacy can theoretically be evaluated based on measurements at practically any wavelength, or in the case of fluorescence, using any reasonable combination of excitation and emission wavelengths.

One issue that has not been addressed in the literature is the effect of TOrC-specific properties on correlation models. In order to explore this concept in greater detail, the absorbance and fluorescence fingerprints of individual target compounds spiked in deionized water $(\sim 10 \mathrm{mg} / \mathrm{L})$ were evaluated (Supplementary Information Appendix 1; SI-A1). Preliminary correlations were developed for compound-specific properties (e.g., maximum absorbance wavelength, excitation and emission wavelengths corresponding to maximum fluorescence), but these correlations did not provide any significant benefits over $\Delta U_{254}$ or $\Delta \mathrm{TF}$. Based on these observations, there was insufficient evidence to justify selection of compound-specific parameters. Therefore, the empirical correlations described below were based on the bulk organic parameters most commonly discussed in practice $\left(\Delta U_{254}\right)$ and research $(\Delta \mathrm{TF})$.

After aggregating the $\Delta \mathrm{UV}_{254}$ and $\Delta \mathrm{TF}$ data from the nine sets of bench-scale experiments (Fig. 2), the reductions in $\mathrm{UV}_{254}$ absorbance and total fluorescence were described by the equations below. The models based on a specific $\mathrm{H}_{2} \mathrm{O}_{2}: \mathrm{O}_{3}$ ratio sometimes provide stronger correlations than the generic model.

$$
\begin{aligned}
& \text { All } \mathrm{H}_{2} \mathrm{O}_{2}: \mathrm{O}_{3}: \Delta \mathrm{UV}_{254}(\%)=100 * 0.46\left(\mathrm{O}_{3}: \mathrm{TOC}\right)^{0.53} R^{2}=0.87 \\
& \text { All } \mathrm{H}_{2} \mathrm{O}_{2}: \mathrm{O}_{3}: \Delta \mathrm{TF}(\%)=100 * 0.83\left(\mathrm{O}_{3}: \mathrm{TOC}\right)^{0.35} R^{2}=0.77 \\
& \mathrm{H}_{2} \mathrm{O}_{2}: \mathrm{O}_{3}=0: \Delta \mathrm{UV}_{254}(\%)=100 * 0.51\left(\mathrm{O}_{3}: \mathrm{TOC}\right)^{0.63} R^{2}=0.92 \\
& \mathrm{H}_{2} \mathrm{O}_{2}: \mathrm{O}_{3}=0: \Delta \mathrm{TF}(\%)=100 * 0.85\left(\mathrm{O}_{3}: \mathrm{TOC}\right)^{0.37} R^{2}=0.78 \\
& \mathrm{H}_{2} \mathrm{O}_{2}: \mathrm{O}_{3}=0.5: \Delta U V_{254}(\%)=100 * 0.45\left(\mathrm{O}_{3}: \mathrm{TOC}\right)^{0.48} R^{2}=0.90 \\
& \mathrm{H}_{2} \mathrm{O}_{2}: \mathrm{O}_{3}=0.5: \Delta \mathrm{TF}(\%)=100 * 0.84\left(\mathrm{O}_{3}: \mathrm{TOC}\right)^{0.33} R^{2}=0.77 \\
& \mathrm{H}_{2} \mathrm{O}_{2}: \mathrm{O}_{3}=1.0: \Delta U \mathrm{UV}_{254}(\%)=100 * 0.42\left(\mathrm{O}_{3}: \mathrm{TOC}\right)^{0.45} R^{2}=0.86
\end{aligned}
$$
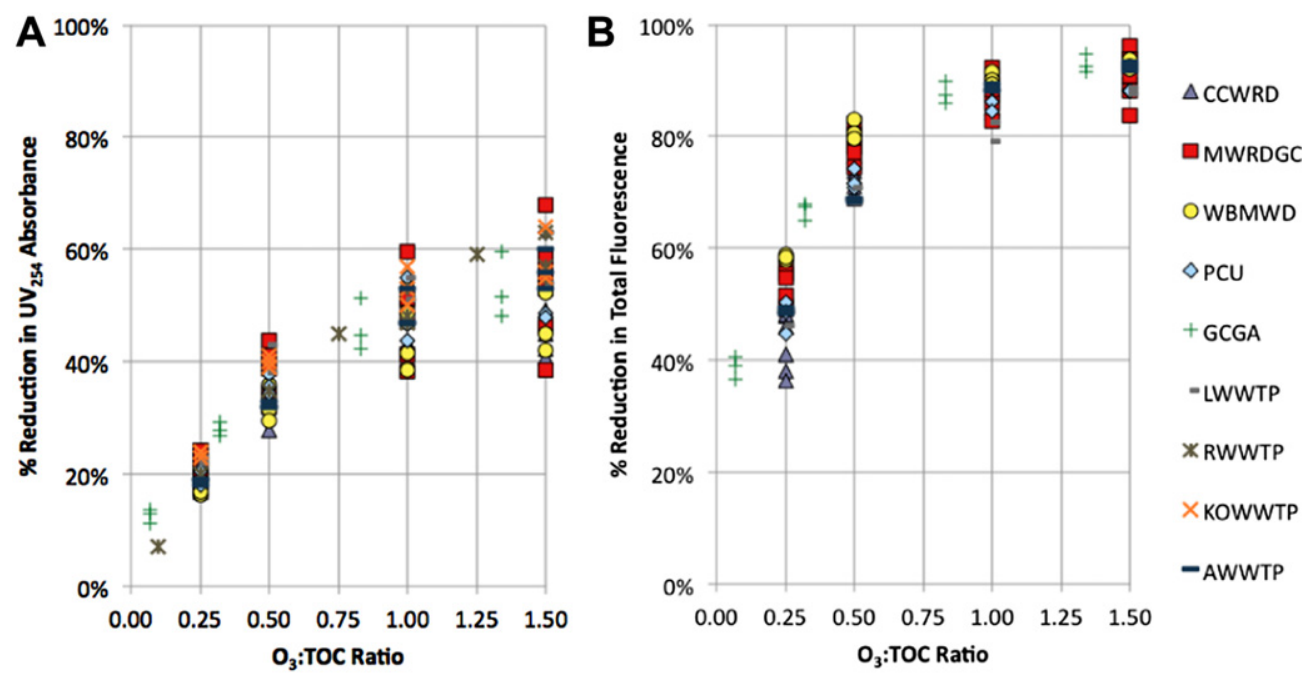

Fig. 2 - Relative reductions in (A) $U_{254}$ absorbance $\left(\Delta U V_{254}\right)$ and (B) total fluorescence $(\Delta T F)$ for the nine secondary effluents after ozonation $\left(\mathrm{H}_{2} \mathrm{O}_{2}: \mathrm{O}_{3}=0-1.0\right)$ in the laboratory systems. 
$\mathrm{H}_{2} \mathrm{O}_{2}: \mathrm{O}_{3}=1.0: \Delta \mathrm{TF}(\%)=100 * 0.81\left(\mathrm{O}_{3}: \mathrm{TOC}\right)^{0.35} R^{2}=0.77$

\subsection{Development of TOrC correlations}

The first step in developing the empirical correlation models was to plot the relative elimination of the target compounds (in \%) against the relative changes in both $\mathrm{UV}_{254}$ absorbance $\left(\Delta \mathrm{UV}_{254}\right.$ in \%) and total fluorescence ( $\Delta \mathrm{TF}$ in \%). Fig. 3 provides examples for sulfamethoxazole and meprobamate, and Appendix SI-A2 provides the remaining scatter plots for each target compound. Each marker represents a single ozone or ozone $/ \mathrm{H}_{2} \mathrm{O}_{2}$ dosing condition. Filtered versus unfiltered (SI-A3) and ozone versus ozone $/ \mathrm{H}_{2} \mathrm{O}_{2}$ samples (SI-A4) were not differentiated in Fig. 3 and SI-A2 because they did not yield noticeably different results. With respect to peroxide addition (SI-A4), several of the plots indicate that $\mathrm{H}_{2} \mathrm{O}_{2}: \mathrm{O}_{3}$ ratios had a very slight impact on the correlation models, specifically for the more resistant compounds. The addition of $\mathrm{H}_{2} \mathrm{O}_{2}$ caused slight decreases in process efficacy for reducing $\mathrm{UV}_{254}$ absorbance and fluorescence, but the corresponding effects on contaminant concentrations were generally insignificant. Since the impact was minimal, all of the ozone and ozone/ $\mathrm{H}_{2} \mathrm{O}_{2}$ data were grouped into a single dataset (Fig. 3 and SI-A2) prior to developing the final correlations.

Due to the empirical nature of these correlations, some degree of scatter was anticipated. However, based on the overlapping data points in Fig. 3 and SI-A2, there was no apparent difference between the various water matrices on a compound-specific basis. In contrast, there were dramatic differences between contaminants, which can be explained by their reactivity with ozone and/or $\cdot \mathrm{OH}$ (Table 2). Therefore, individual correlations were developed for each target

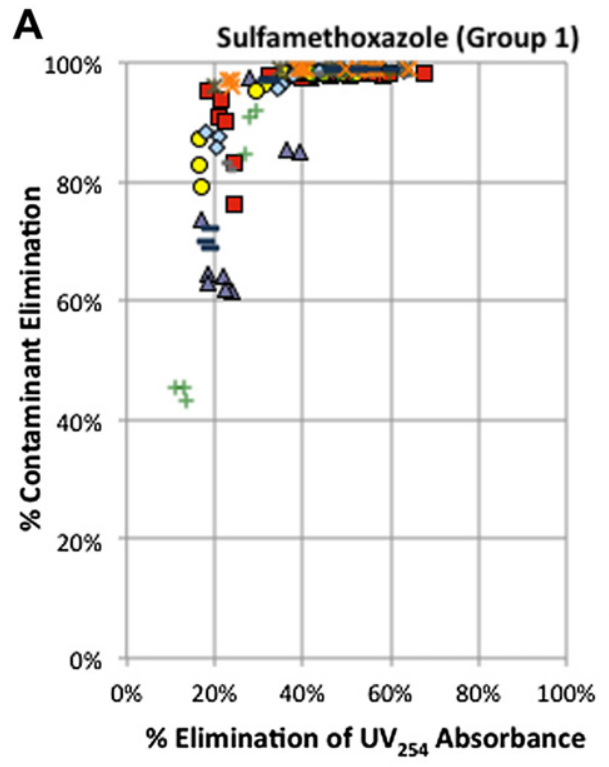

\section{B}

\begin{tabular}{|l|}
\hline$\triangle C C W R D$ \\
-MWRDGC \\
OWBMWD \\
OPCU \\
+ GCGA \\
-LWWTP \\
XRWWTP \\
$\times$ KOWWTP \\
-AWWTP \\
\hline
\end{tabular}
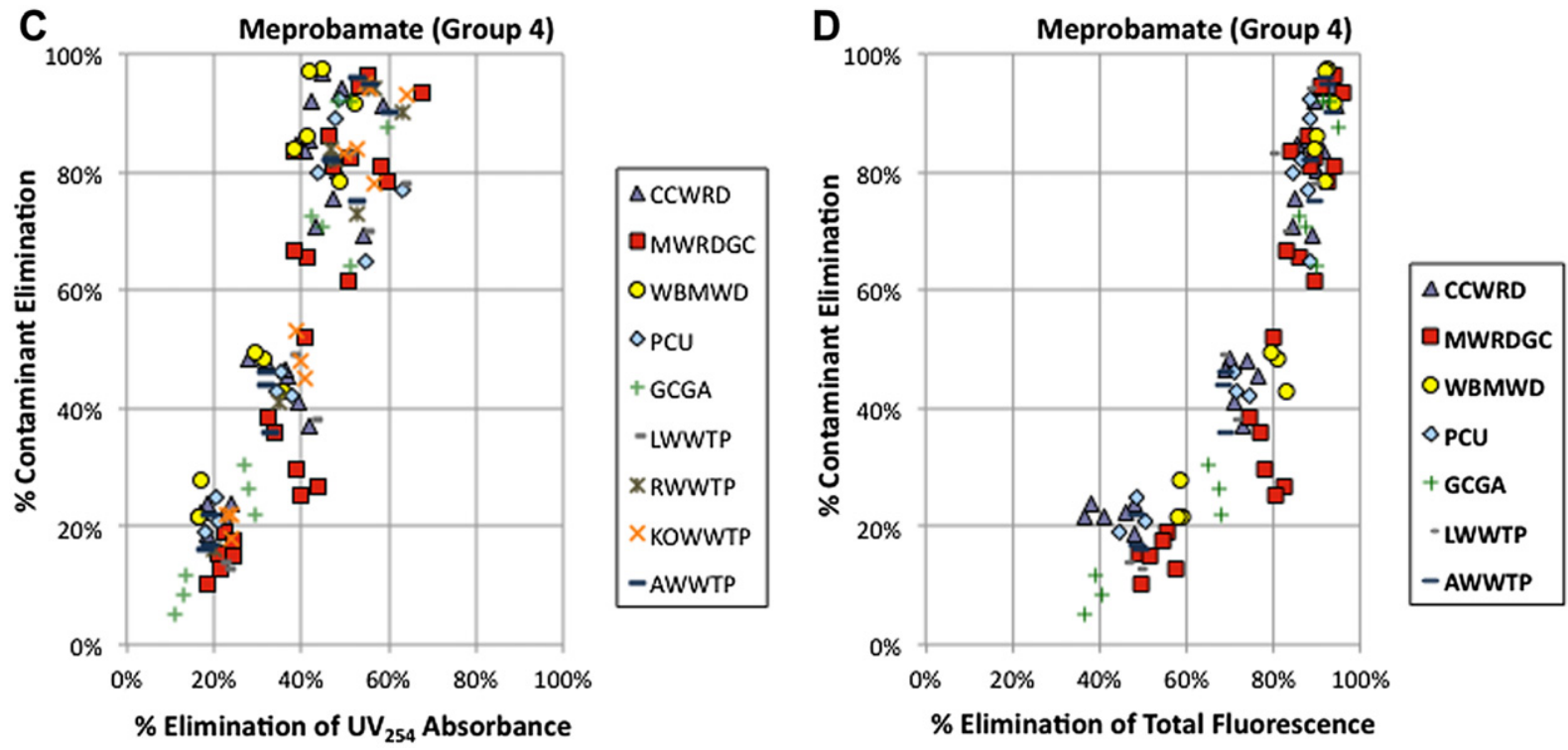

Fig. 3 - Example correlations between the \% elimination of (A) $U_{254}$ absorbance and Group 1 compound sulfamethoxazole, (B) total fluorescence and sulfamethoxazole, (C) $\mathrm{UV}_{254}$ absorbance and Group 4 compound meprobamate, and (D) total fluorescence and meprobamate. The remaining correlations are illustrated in SI-A2 through SI-A6. 
compound according to Eq. (9), and the corresponding regression parameters are summarized in Table 3. These correlations focus on the linear portion of the decay curves due to practical treatment limitations for most compounds (i.e., maximum practical removal $<99 \%$ ). For the fast-reacting compounds, the concentrations rapidly approached their respective MRLs even at the lowest $\mathrm{O}_{3}$ :TOC ratio (i.e., nearly vertical lines). Since the data that were $<$ MRL would distort the linear regression analyses, some of the data points were excluded, as indicated by the " $\mathrm{N}_{\mathrm{UV}}$ " or " $\mathrm{N}_{\mathrm{TF}}$ " parameter for each compound. The compounds within the same group were treated similarly in order to reduce any artificial biases.

$$
\begin{aligned}
\left(1-\frac{[\mathrm{C}]}{\left[\mathrm{C}_{0}\right]}\right) * 100(\%)= & \text { Slope } *\left[\left(1-\frac{\mathrm{UV} \text { or } \mathrm{TF}}{\mathrm{UV}_{0} \text { or } \mathrm{TF}_{0}}\right) * 100(\%)\right] \\
& + \text { Intercept }
\end{aligned}
$$

The target compounds were separated into five groups based on their reactivity with ozone and $\cdot \mathrm{OH}$. These differences in reactivity affected the magnitudes of their slopes and vertical intercepts, which will be described below. Table 3 also provides regression parameters for a representative "Indicator" in each group based on all of the constituent compounds combined. Finally, Table 4 summarizes the required removals of the organic surrogate parameters to achieve various treatment thresholds (i.e., $90 \%$ removal or the relevant CDPH requirement).

For Group 1, the contaminant degradation profiles were so steep, as illustrated in Fig. 3A, that it was not possible to describe the removal rate based on $\Delta U^{254}$ (i.e., $R^{2}<0.2$ ). Although it was possible to develop correlation models with $\Delta \mathrm{TF}$, the correlations were relatively weak (i.e., $R^{2}<0.57$ ). With respect to the $\Delta$ TF models in Table 3 , the Group 1 compounds were generally characterized by high slopes (>1.6) with low vertical intercepts $(<10)$ or low slopes $(<1.6)$ with high vertical intercepts $(>10)$. The high slopes indicate rapid reaction rates, as would be expected for these compounds, and the low vertical intercepts indicate that elimination of these particular compounds started at the same time as the elimination of $\mathrm{UV}_{254}$ absorbance and total fluorescence. In contrast, the fastest reacting compounds, including triclosan, bisphenol A, and diclofenac, had lower slopes because their oxidation started quicker than that of $\mathrm{UV}_{254}$ absorbance and total

\begin{tabular}{|c|c|c|c|c|c|c|c|}
\hline \multirow[t]{2}{*}{ Contaminant } & \multirow[t]{2}{*}{$\mathrm{N}_{\mathrm{UV}} \mid \mathrm{N}_{\mathrm{TF}}$} & \multicolumn{3}{|c|}{$\mathrm{UV}_{254}$ absorbance } & \multicolumn{3}{|c|}{ Total fluorescence } \\
\hline & & Slope & Intercept & $R^{2}$ & Slope & Intercept & $R^{2}$ \\
\hline \multicolumn{8}{|l|}{ Group $1^{a}$} \\
\hline Bisphenol A & $30 \mid 26$ & N/A & & & 1.33 & 22 & 0.56 \\
\hline Carbamazepine & $30 \mid 26$ & N/A & & & 1.72 & -3 & 0.53 \\
\hline Diclofenac & $30 \mid 26$ & N/A & & & 1.48 & 12 & 0.56 \\
\hline Naproxen & $30 \mid 26$ & N/A & & & 1.74 & -4 & 0.55 \\
\hline Sulfamethoxazole & $30 \mid 26$ & N/A & & & 1.66 & -6 & 0.54 \\
\hline Triclosan & $30 \mid 26$ & N/A & & & 1.00 & 41 & 0.57 \\
\hline Trimethoprim & $30 \mid 26$ & N/A & & & 1.60 & 4 & 0.50 \\
\hline Indicator & $210 \mid 182$ & N/A & & & 1.51 & 10 & 0.47 \\
\hline \multicolumn{8}{|l|}{ Group $2^{a}$} \\
\hline Atenolol & $60 \mid 52$ & 2.37 & -4 & 0.79 & 1.55 & -33 & 0.83 \\
\hline Gemfibrozil & $60 \mid 52$ & 1.80 & 31 & 0.62 & 1.32 & 0 & 0.77 \\
\hline Indicator & $120 \mid 104$ & 2.08 & 13 & 0.59 & 1.43 & -17 & 0.68 \\
\hline \multicolumn{8}{|l|}{ Group $3^{a}$} \\
\hline DEET & $60 \mid 52$ & 1.59 & -2 & 0.67 & 1.07 & -24 & 0.76 \\
\hline Ibuprofen & $60 \mid 52$ & 1.62 & 5 & 0.64 & 1.15 & -20 & 0.77 \\
\hline pCBA & $42 \mid 42$ & 1.31 & 3 & 0.48 & 0.86 & -15 & 0.54 \\
\hline Phenytoin & $60 \mid 52$ & 1.72 & 2 & 0.60 & 1.16 & -22 & 0.66 \\
\hline Primidone & $60 \mid 52$ & 1.54 & -1 & 0.65 & 1.05 & -22 & 0.74 \\
\hline Indicator & $282 \mid 250$ & 1.58 & 1 & 0.58 & 1.06 & -20 & 0.65 \\
\hline \multicolumn{8}{|l|}{ Group $4^{\mathrm{a}}$} \\
\hline 1,4-Dioxane & $40 \mid 40$ & 1.57 & -18 & 0.69 & 1.29 & -57 & 0.70 \\
\hline Atrazine & $124 \mid 104$ & 1.79 & -21 & 0.76 & 1.46 & -61 & 0.80 \\
\hline Meprobamate & $124 \mid 104$ & 1.87 & -16 & 0.64 & 1.53 & -59 & 0.82 \\
\hline Indicator & $288 \mid 248$ & 1.80 & -19 & 0.74 & 1.46 & -59 & 0.76 \\
\hline \multicolumn{8}{|l|}{ Group $5^{a}$} \\
\hline TCEP & $121 \mid 101$ & 0.57 & -7 & 0.56 & 0.44 & -19 & 0.56 \\
\hline \multicolumn{8}{|c|}{ Microbial inactivation ${ }^{\mathrm{b}}$} \\
\hline E. coli & 95 | 95 & 0.13 & -1.2 & 0.47 & 0.10 & -3.6 & 0.46 \\
\hline MS2 & $94 \mid 94$ & 0.14 & -0.1 & 0.71 & 0.11 & -3.4 & 0.78 \\
\hline Bacillus Spores & $15 \mid 15$ & N/A & N/A & & & & \\
\hline
\end{tabular}

Table 3 - Summary of regression parameters.

$\mathrm{N}_{\mathrm{UV}}$ and $\mathrm{N}_{\mathrm{TF}}$ refer to the number of data point used in the development of the regression parameters.

a \% compound elimination vs. \% organic surrogate elimination (see Eq. (9)).

b Log inactivation vs. \% organic surrogate elimination (see Eq. (19)). 
Table 4 - Required elimination of organic surrogates to achieve treatment thresholds.

\begin{tabular}{|c|c|c|c|c|c|}
\hline \multirow[t]{2}{*}{ Contaminant } & \multirow{2}{*}{$\begin{array}{c}\text { CDPH } \\
\text { Group } \\
\text { and } \\
\text { objective }\end{array}$} & \multicolumn{4}{|c|}{ CDPH objective $90 \%$ elimination } \\
\hline & & $\mathrm{UV}_{254}$ & $\mathrm{TF}$ & $\mathrm{UV}_{254}$ & $\mathrm{TF}$ \\
\hline \multicolumn{6}{|l|}{ Group 1} \\
\hline Bisphenol A & A $\mid 69 \%$ & $\sim 20 \%$ & $35 \%$ & $\sim 20 \%$ & $51 \%$ \\
\hline Carbamazepine & C | $69 \%$ & $\sim 20 \%$ & $42 \%$ & $\sim 20 \%$ & $54 \%$ \\
\hline Diclofenac & $\mathrm{D} \mid 69 \%$ & $\sim 20 \%$ & $39 \%$ & $\sim 20 \%$ & $53 \%$ \\
\hline Naproxen & $\mathrm{E} \mid 69 \%$ & $\sim 20 \%$ & $42 \%$ & $\sim 20 \%$ & $54 \%$ \\
\hline Sulfamethoxazole & $B \mid 69 \%$ & $\sim 20 \%$ & $45 \%$ & $\sim 20 \%$ & $58 \%$ \\
\hline Triclosan & A $\mid 69 \%$ & $\sim 20 \%$ & $28 \%$ & $\sim 20 \%$ & $49 \%$ \\
\hline $\begin{array}{l}\text { Trimethoprim } \\
\text { Group } 2\end{array}$ & D $\mid 69 \%$ & $\sim 20 \%$ & $41 \%$ & $\sim 20 \%$ & $54 \%$ \\
\hline Atenolol & D | $69 \%$ & $31 \%$ & $66 \%$ & $40 \%$ & $79 \%$ \\
\hline Gemfibrozil & $\mathrm{F} \mid 69 \%$ & $21 \%$ & $52 \%$ & $33 \%$ & $68 \%$ \\
\hline \multicolumn{6}{|l|}{ Group 3} \\
\hline DEET & G $69 \%$ & $45 \%$ & $87 \%$ & $58 \%$ & $>100 \%$ \\
\hline Ibuprofen & $\mathrm{G} \mid 69 \%$ & $40 \%$ & $77 \%$ & $52 \%$ & $96 \%$ \\
\hline pCBA & G $69 \%$ & $50 \%$ & $98 \%$ & $66 \%$ & $>100 \%$ \\
\hline Phenytoin & G $69 \%$ & $39 \%$ & $78 \%$ & $51 \%$ & $97 \%$ \\
\hline $\begin{array}{l}\text { Primidone } \\
\text { Group } 4\end{array}$ & G $69 \%$ & $45 \%$ & $87 \%$ & $59 \%$ & $>100 \%$ \\
\hline 1,4-Dioxane & $-69 \%$ & $55 \%$ & $98 \%$ & $69 \%$ & $>100 \%$ \\
\hline Atrazine & D $69 \%$ & $50 \%$ & $89 \%$ & $62 \%$ & $>100 \%$ \\
\hline $\begin{array}{l}\text { Meprobamate } \\
\text { Group } 5\end{array}$ & $\mathrm{H} \mid 50 \%$ & $35 \%$ & $71 \%$ & $57 \%$ & $97 \%$ \\
\hline TCEP & $\mathrm{H} \mid 50 \%$ & $>100 \%$ & $>100 \%$ & $>100 \%$ & $>100 \%$ \\
\hline
\end{tabular}

fluorescence, which translated into vertical shifts in the regressions.

The degradation profiles for the Group 2 compounds were different from the other compound groups, thereby justifying a unique classification, but the reaction rates for the constituent compounds (gemfibrozil and atenolol) also differed by an order of magnitude. This was apparent in the different regression properties in Table 3 , but the models still indicated fast reaction rates by either a high slope or vertical intercept. Fewer data points were excluded from the Group 2 analysis due to the greater resistance of these compounds to oxidation. Due to the reduced reactivity, regression analyses for both $\Delta \mathrm{UV}_{254}$ and $\Delta \mathrm{TF}$ were possible.

For the Group 3 compounds, the $\Delta \mathrm{UV}_{254}$ models consistently had slopes of 1.7 or lower and vertical intercepts $<5$ (Table 3). Again, this indicates that contaminant oxidation initiated at the same time as the changes in $\mathrm{UV}_{254}$ absorbance but at a much faster rate. For the total fluorescence models, the slopes were generally $<1.1$, while the vertical intercepts were consistently negative (Table 3 ). Therefore, the Group 3 compounds experienced a lag in oxidation in comparison to reductions in total fluorescence, but the changes then occur at approximately the same rate.

The Group 4 compounds demonstrated significant lags in oxidation compared to elimination of $\mathrm{UV}_{254}$ absorbance and total fluorescence, as indicated by the negative vertical intercepts (Table 3), and the fluorescence models were also characterized by slightly exponential trends (Fig. 3). This is consistent with the group's low to moderate reactivity with ozone and $\cdot \mathrm{OH}$.
As would be expected, TCEP (Group 5) was characterized by extremely small slopes and negative intercepts (Table 3), which indicate that TCEP oxidation starts much later and at a much slower rate than changes in $\mathrm{UV}_{254}$ absorbance and total fluorescence. TCEP also had one of the weaker correlations, presumably due to its resistance to oxidation. In fact, the oxidation of TCEP failed to reach $40 \%$ with the target ozone doses, thereby providing a limited range of reduction to evaluate with linear regression. It is important to note that musk ketone would also be included in Group 5, but it was not possible to quantify this compound during the bench-scale experiments (see Materials and methods). Since musk ketone and TCEP are characterized by similar resistance to oxidation, the regression parameters for musk ketone would likely be similar to those of TCEP. Therefore, $\Delta U_{254}$ and $\Delta T F$ are poor surrogates for TCEP and musk ketone in relation to the CDPH framework and the $90 \%$ threshold since the required elimination of $\mathrm{UV}_{254}$ absorbance and total fluorescence exceeded the bounds of the model (i.e., $>100 \%$ ).

\subsection{Modeling $\cdot \mathrm{OH}$ exposure with correlations}

In addition to estimating transformation of the target compounds, the aforementioned correlations can also be used to estimate overall $\cdot \mathrm{OH}$ exposure with ozone or ozone $/ \mathrm{H}_{2} \mathrm{O}_{2}$. Eq. (10) represents the linear correlation model for pCBA (regression parameters from Table 3), and Eq. (11) illustrates the process for calculating overall $\cdot \mathrm{OH}$ exposure based on changes in pCBA concentrations during advanced oxidation. By combining Eqs. (10) and (11), the $\cdot \mathrm{OH}$ exposure models in Eqs. (12) and (13) can be derived.

$$
\begin{aligned}
\left(1-\frac{[\mathrm{pCBA}]}{[\mathrm{pCBA}]_{0}}\right) * 100(\%)= & \text { Slope } *\left[\left(1-\frac{\mathrm{UV} \text { or TF }}{\mathrm{UV}_{0} \text { or TF }}\right) * 100(\%)\right] \\
& + \text { Intercept }
\end{aligned}
$$

$\int[\cdot \mathrm{OH}] \mathrm{dt}(\mathrm{Ms})=\frac{\ln \left(\frac{[\mathrm{pCBA}]}{[\mathrm{pCBA}]_{0}}\right)}{-5 \times 10^{9} \mathrm{M}^{-1} \mathrm{~s}^{-1}}$

$$
\begin{aligned}
& \Delta \mathrm{UV}_{254} \text { Model : } \int[\cdot \mathrm{OH}] \mathrm{dt}(\mathrm{Ms}) \\
& \quad=\frac{\ln \left(-0.0131 *\left[\left(1-\frac{\mathrm{UV}}{\mathrm{UV}_{0}}\right) * 100(\%)\right]+0.97\right)}{-5 \times 10^{9}}
\end{aligned}
$$

$$
\begin{aligned}
\Delta \text { TF Model: } & \int[\cdot \mathrm{OH}] \mathrm{dt}(\mathrm{Ms}) \\
& =\frac{\ln \left(-0.0086 *\left[\left(1-\frac{\mathrm{TF}}{\mathrm{TF}_{0}}\right) * 100(\%)\right]+1.15\right)}{-5 \times 10^{9}}
\end{aligned}
$$

Therefore, instead of spiking and analyzing for changes in pCBA concentration, one can use $\Delta U_{254}$ or $\Delta T F$ to develop a rough estimate of overall $\cdot \mathrm{OH}$ exposure. This method for calculating $\cdot \mathrm{OH}$ exposures can then be used to estimate the elimination of recalcitrant TOrCs (i.e., contribution from ozone assumed to be negligible) based on kinetics, particularly for compounds that do not have established correlation models. For example, a 35\% reduction in $\mathrm{UV}_{254}$ absorbance during ozonation of secondary effluent corresponds to an $\cdot \mathrm{OH}$ 
exposure of $1.34 \times 10^{-10} \mathrm{Ms}$ based on the aforementioned pCBA model (Eq. (14)).

$$
\begin{aligned}
\Delta \mathrm{UV}_{254}= & 35 \%: \quad \int[\cdot \mathrm{OH}] \mathrm{dt}(\mathrm{Ms})=\frac{\ln (-0.0131 * 35+0.97)}{-5 \times 10^{9}} \\
& =1.34 \times 10^{-10} \mathrm{Ms}
\end{aligned}
$$

The corresponding elimination of meprobamate can be estimated directly from its $\Delta U_{254}$ correlation (49\%; Table 3 and Eq. (15)) or from kinetics (42\%; Eq. (16)-(18)) using a combination of the estimated $\cdot \mathrm{OH}$ exposure and the $\cdot \mathrm{OH}$ reaction rate constant $\left(4.0 \times 10^{9} \mathrm{M}^{-1} \mathrm{~s}^{-1}\right.$; see Table 2$)$. Since the reactivity between meprobamate and ozone is low, this reaction can be ignored.

$\Delta \mathrm{UV}_{254}=35 \%:\left(1-\frac{[\mathrm{C}]}{\left[\mathrm{C}_{0}\right]}\right) * 100(\%)=1.87 * 35-16=49 \%$

$\ln \left(\mathrm{C} / \mathrm{C}_{0}\right)=-(\mathrm{k} \cdot \mathrm{OH})\left(\int[\cdot \mathrm{OH}] \mathrm{dt}\right)$,

where the contribution from ozone is assumed to be negligible.

$\ln \left(\mathrm{C} / \mathrm{C}_{0}\right)=-\left(4.0 \times 10^{9} \mathrm{M}^{-1} \mathrm{~s}^{-1}\right)\left(1.34 \times 10^{-10} \mathrm{Ms}\right)=-0.54$

$\left(1-\frac{[C]}{\left[C_{0}\right]}\right) * 100(\%)=(1-\exp (-0.54)) * 100(\%)=42 \%$

These estimates can be compared to the experimental observations for meprobamate in Fig. 3. The models proposed in Eqs. (12) and (13) represent a first approximation to assess -OH exposure using on-line instrumentation. Additional studies are needed to further validate this approach in pilotand full-scale systems.

\subsection{Development of microbial correlations}

The $\Delta U_{254}$ and $\Delta T F$ correlations for the target microbes are provided in Table 3 and SI-A2 through SI-A4. In contrast with the target compounds for which the upper bound of elimination was generally $<99 \%$, the microbial correlations were based on log inactivation rather than percent reductions in concentrations, as described in Eq. (19):

$-\log \left(\frac{\mathrm{N}}{\mathrm{N}_{0}}\right)=$ Slope $*\left[\left(1-\frac{\mathrm{UVorTF}}{\mathrm{UV}_{0} \text { orTF }_{0}}\right) * 100(\%)\right]+$ Intercept

Therefore, the slopes and intercepts cannot be compared directly to those of the target compounds. In addition, the correlations for the surrogate microbes generally exhibited greater variability than those of the target compounds, which was also observed in Bahr et al. (2007). It is interesting to note that the inactivation of E. coli and MS2 was quite comparable, which indicates that $E$. coli could possibly be used as a surrogate for some viruses, but MS2 demonstrated stronger correlations than E. coli (Table 3). With respect to B. subtilis, the spores required extended exposure to ozone before any inactivation was observed (SI-A2 through SI-A4), which is consistent with the lag phase described by Driedger et al. (2001). Therefore, it was not possible to accurately correlate $B$. subtilis spore inactivation with $\Delta \mathrm{UV}_{254}$ or $\Delta \mathrm{TF}$. In fact, nearly $50 \%$ and $90 \%$ reductions in $\mathrm{UV}_{254}$ absorbance and total fluorescence, respectively, were required before any inactivation was observed, but the inactivation was very rapid after that threshold was achieved.

\subsection{Pilot-scale validation}

As shown in Fig. 4A, Fig. 4B, and SI-A5, there was relatively good agreement between the bench- (indicated by WRF-09-10 markers) and pilot-scale correlations, which highlights the widespread applicability of this concept to diverse water qualities and treatment scales. As with the bench-scale data, the contaminant correlations proved to be much stronger than the microbial correlations, particularly in the case of $E$. coli. Therefore, the use of $\Delta \mathrm{UV}_{254}$ or $\Delta \mathrm{TF}$ may be limited to general process performance and contaminant oxidation, while disinfection may still require more traditional frameworks (e.g., the CT concept) to describe expected levels of inactivation.
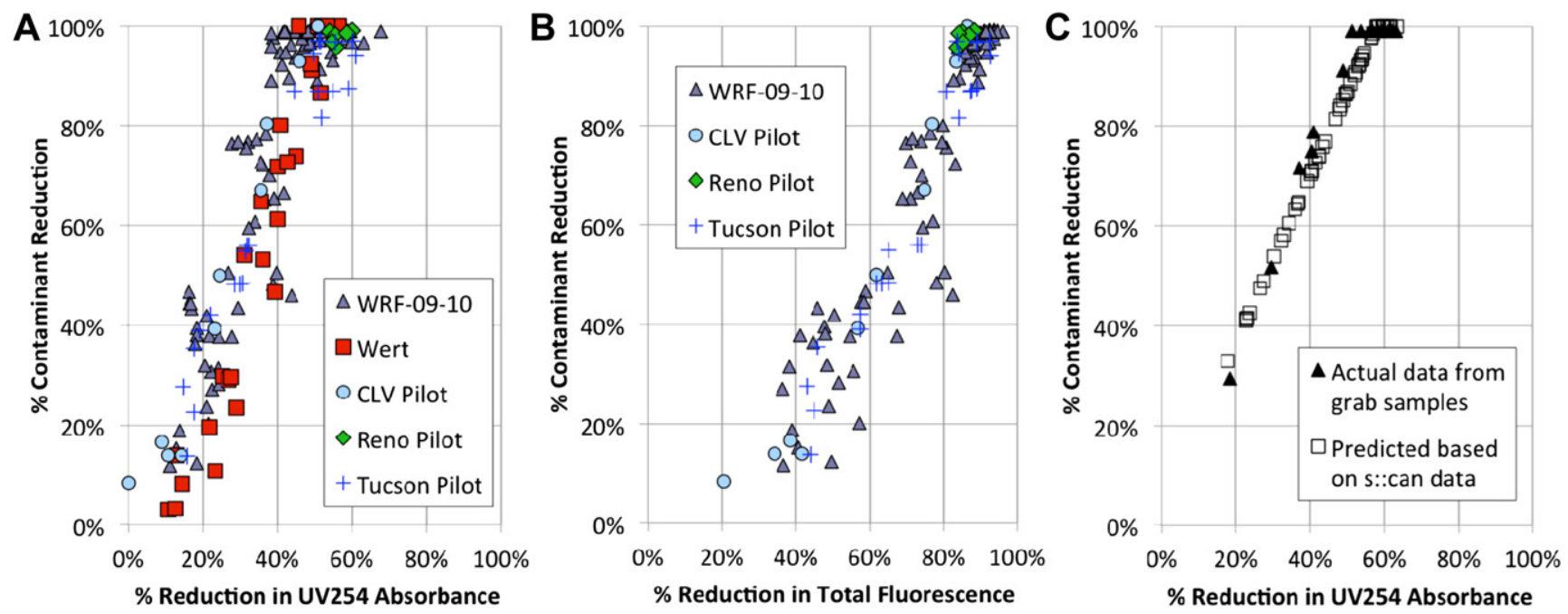

Fig. 4 - Validation of the (A) $\Delta U V_{254}$ and (B) $\Delta T F$ correlations for phenytoin based on grab samples at the various pilot-scale sites. The validation of the data from the s::can spectro::lyser is illustrated in (C). The remaining pilot-scale validations are illustrated in SI-A5 and SI-A6. 


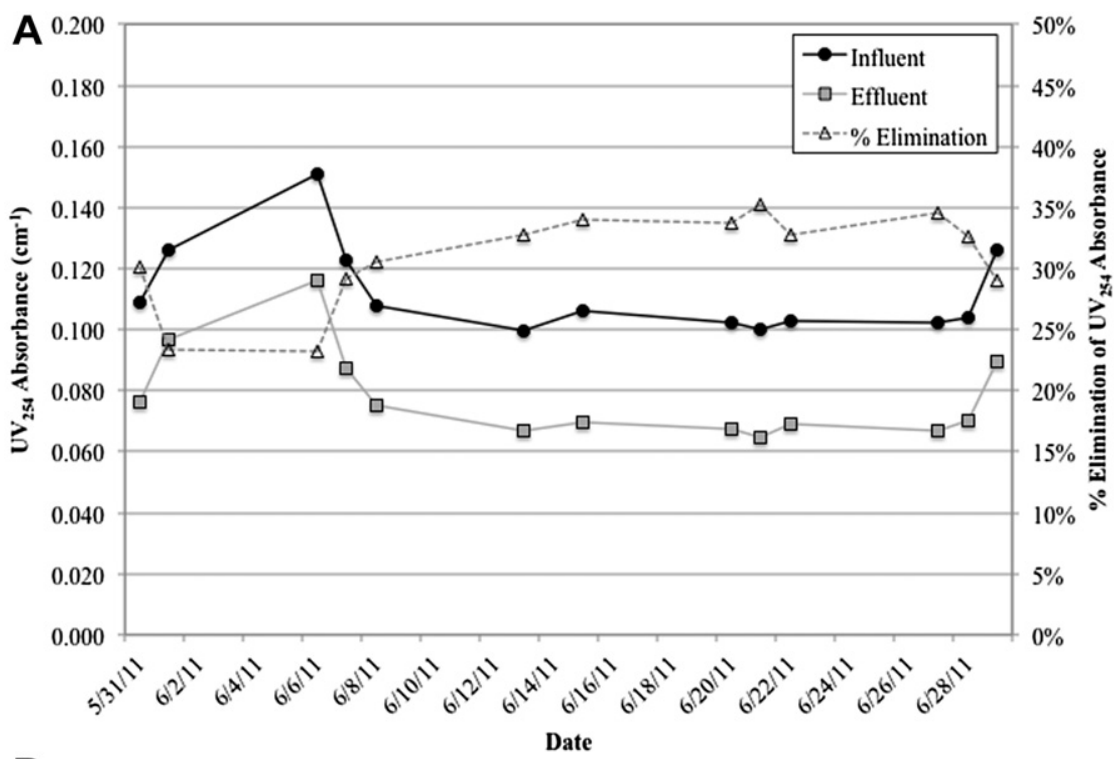

B

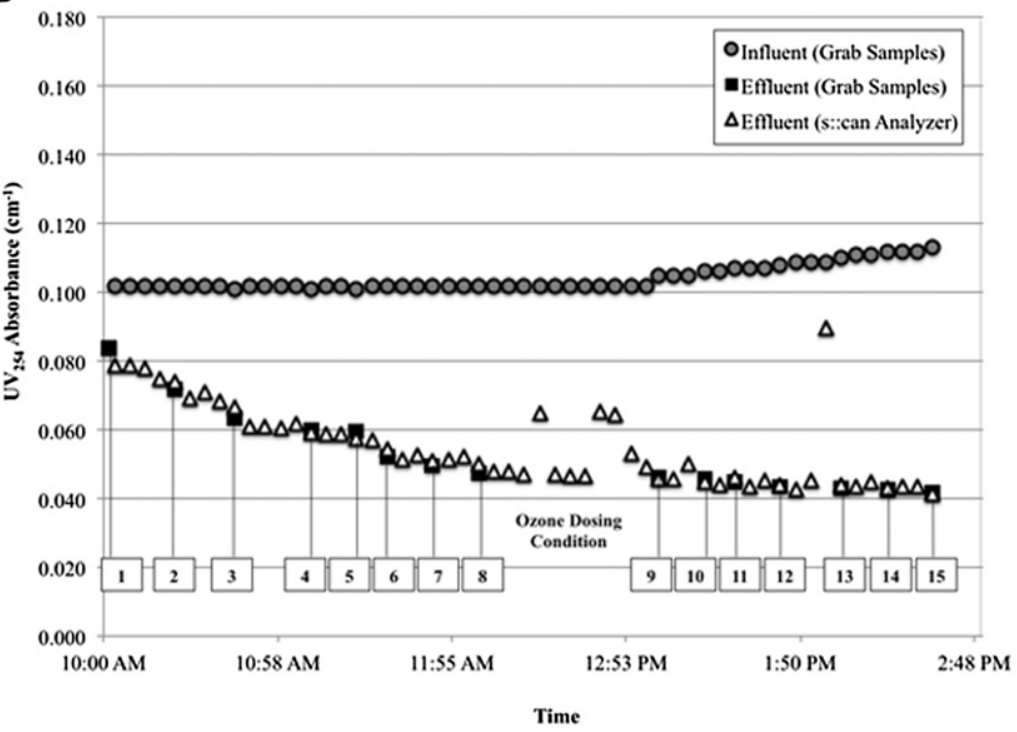

Fig. 5 - (A) Influent and effluent $\mathrm{UV}_{254}$ absorbance grab samples from the ozone process at the CLV pilot. (B) Comparison of grab samples and online analyzer data for $\mathrm{UV}_{254}$ absorbance at the CLV pilot. The ozone dosing conditions (i.e., 1-15) are described in Table $\mathbf{S} 1$.

With respect to the CLV pilot, a series of grab samples was collected to evaluate the continuous operation of the ozone pilot and validate the data from the online $U_{254}$ absorbance analyzer. Fig. 5A illustrates the temporal variability in $\mathrm{UV}_{254}$ absorbance prior to and after ozonation in addition to the corresponding differentials. Although the $\mathrm{UV}_{254}$ absorbance prior to ozonation fluctuated over time, the constant ozone dose applied during this period $\left(1.5 \mathrm{mg} / \mathrm{L} ; \mathrm{O}_{3}: \mathrm{TOC}=0.25 ; \mathrm{H}_{2} \mathrm{O}_{2}: \mathrm{O}_{3}=0\right)$ resulted in a consistent $\Delta \mathrm{UV}_{254}$ of approximately $30 \%$.

In addition to the grab samples in Fig. 5A, Fig. S2A illustrates the fluctuation in $\mathrm{UV}_{254}$ absorbance for the MBR filtrate prior to ozonation, which was continuously monitored from May 21st through May 31st of 2011 with the online analyzer. The grab sample toward the end of the monitoring period was used as a preliminary validation between the online analyzer and laboratory data. Fig. S2B illustrates the continuous monitoring data for the ozonated MBR filtrate from May 31st to July 4th of 2011. In contrast with the relatively stable signal before ozonation, the signal after ozonation experienced rapid fluctuations due to analyzer interference. In order to improve the clarity of the data, any erroneous values $>0.100 \mathrm{~cm}^{-1}$ were removed from the data set and attributed to the following reasons: unexpected or planned shutdowns of the pilot systems, scaling or biological fouling of the analyzer, and periodic spikes in turbidity or air bubbles that interrupted the light path in the flow cell. Ensuring continuous flow through the analyzer and implementing a routine cleaning and maintenance schedule (e.g., daily instead of weekly) would likely be required to mitigate these problems in the future. However, this preliminary data set indicates that online 
monitoring of $\mathrm{UV}_{254}$ absorbance is a promising operational tool.

In addition to the long-term monitoring data, a one-day, variable ozone dose experiment was also performed to validate the empirical TOrC correlations. Fig. 5B illustrates the resulting data from both grab and continuous monitoring samples, where the numbered boxes represent different dosing conditions $\left(\mathrm{O}_{3}=0.6-9.0 \mathrm{mg} / \mathrm{L} ; \mathrm{O}_{3}\right.$ :TOC $=0.1-2.0$; see Table S1 for details). During the short timeframe of the variable dose experiment, the influent water quality (shaded circles) was relatively stable, and the data demonstrate good consistency between the online (empty triangles) versus grab sample (black squares) data. Fig. 4C and SI-A6 illustrate the use of these grab samples and online data to validate the TOrC correlations.

With the exception of ibuprofen and TCEP, the predictive model based on the online absorbance readings and the actual levels of transformation based on the grab samples were consistent. This was particularly true for the highly susceptible Group 1 compounds, which were almost always $<\mathrm{MRL}$ after oxidation, but the data were also relatively consistent for the Group 2, 3, and 4 compounds. It is unclear exactly why the actual data and the predictive model for ibuprofen and TCEP were dissimilar. However, the bench-scale TCEP data that were used to develop the correlations also showed more variability than the other compounds. In general, the predictive model tended to overestimate the level of oxidation for some compounds.

\subsection{Full-scale validation}

The full-scale samples indicated that the reductions in $\mathrm{UV}_{254}$ absorbance, total fluorescence, and many of the target compounds at the full-scale facility were similar to the predicted values (Table 5). Exclusions include compounds that were not detected in the ozone influent sample, which were omitted from Table 5; compounds that reached their respective MRLs during ozonation, which limited the quantifiable range; and two specific outliers (DEET and E. coli).

Ozonation only achieved $45 \%$ elimination of DEET, but it is unclear what caused this deviation from the bench-scale correlation. With respect to $E$. coli, the potential level of inactivation was limited to only 3.5 logs since the ozone influent sample only contained $3.5 \times 10^{3} \mathrm{MPN} / 100 \mathrm{~mL}$. It is easier to achieve several orders of magnitude of inactivation when the initial E. coli level is high, such as in a spiked bench-scale experiment, but it becomes increasingly difficult to inactivate bacteria as the numbers approach the detection limit of the assay, possibly due to shielding. This may be one possible explanation for the discrepancy between the maximum level of inactivation (3.5 logs) and the observed level of inactivation (2.5 logs). With the exception of these two outliers, the models provided relatively accurate predictions of process performance, which highlights the utility of this surrogate framework as an alternative to frequent TOrC monitoring.

\section{Conclusions}

One of the critical components of treatment plant operation is real-time monitoring of process performance that allows for subsequent operational adjustments. As such, the primary goal of this study was to provide operators with tools to predict treatment efficacy and identify breakdowns and inefficiencies in the performance of oxidation processes that rely heavily on fast reacting oxidants, such as ozone and $\cdot \mathrm{OH}$. In order to better integrate ozonation and other AOPs into water

\section{Table 5 - Full-scale validation of $\mathbf{U V}_{\mathbf{2 5 4}}$ absorbance and total fluorescence correlations.}

\begin{tabular}{|c|c|c|c|c|c|}
\hline Parameter & Ozone influent & Ozone effluent & Actual elimination & $\Delta \mathrm{UV}_{254}$ prediction & $\Delta \mathrm{TF}$ prediction \\
\hline \multicolumn{6}{|l|}{ Organic Surrogates } \\
\hline $\mathrm{UV}_{254}$ Absorbance & $0.116 \mathrm{~cm}^{-1}$ & $0.059 \mathrm{~cm}^{-1}$ & $49 \%$ & $51 \%$ & N/A \\
\hline Total Fluorescence & 28,782 (unitless) & 4546 (unitless) & $84 \%$ & N/A & $85 \%$ \\
\hline \multicolumn{6}{|l|}{ Group 1} \\
\hline Carbamazepine & $220 \mathrm{ng} / \mathrm{L}$ & $<10 \mathrm{ng} / \mathrm{L}$ & $<\mathrm{MRL}^{\mathrm{a}}$ & $>99 \%$ & $>99 \%$ \\
\hline Diclofenac & $47 \mathrm{ng} / \mathrm{L}$ & $<25 \mathrm{ng} / \mathrm{L}$ & $<\mathrm{MRL}^{\mathrm{a}}$ & $>99 \%$ & $>99 \%$ \\
\hline Naproxen & $26 \mathrm{ng} / \mathrm{L}$ & $<25 \mathrm{ng} / \mathrm{L}$ & $<\mathrm{MRL}^{\mathrm{a}}$ & $>99 \%$ & $>99 \%$ \\
\hline Sulfamethoxazole & $2200 \mathrm{ng} / \mathrm{L}$ & $<25 \mathrm{ng} / \mathrm{L}$ & $<\mathrm{MRL}^{\mathrm{a}}$ & $>99 \%$ & $>99 \%$ \\
\hline Trimethoprim & $21 \mathrm{ng} / \mathrm{L}$ & $<10 \mathrm{ng} / \mathrm{L}$ & $<\mathrm{MRL}^{\mathrm{a}}$ & $>99 \%$ & $>99 \%$ \\
\hline \multicolumn{6}{|l|}{ Group 2} \\
\hline Atenolol & $190 \mathrm{ng} / \mathrm{L}$ & $<25 \mathrm{ng} / \mathrm{L}$ & $<\mathrm{MRL}^{\mathrm{a}}$ & $>99 \%$ & $96 \%$ \\
\hline Gemfibrozil & $72 \mathrm{ng} / \mathrm{L}$ & $<10 \mathrm{ng} / \mathrm{L}$ & $<\mathrm{MRL}^{\mathrm{a}}$ & $>99 \%$ & $>99 \%$ \\
\hline \multicolumn{6}{|l|}{ Group 3} \\
\hline DEET & 100 ng/L & $55 \mathrm{ng} / \mathrm{L}$ & $45 \%$ & $76 \%$ & $65 \%$ \\
\hline Phenytoin & $150 \mathrm{ng} / \mathrm{L}$ & $17 \mathrm{ng} / \mathrm{L}$ & $89 \%$ & $86 \%$ & $74 \%$ \\
\hline Primidone & 210 ng/L & $45 \mathrm{ng} / \mathrm{L}$ & $79 \%$ & $74 \%$ & $65 \%$ \\
\hline \multicolumn{6}{|l|}{ Group 4} \\
\hline Meprobamate & $350 \mathrm{ng} / \mathrm{L}$ & $110 \mathrm{ng} / \mathrm{L}$ & $69 \%$ & $76 \%$ & $68 \%$ \\
\hline \multicolumn{6}{|l|}{ Group 5} \\
\hline TCEP & $410 \mathrm{ng} / \mathrm{L}$ & 340 ng/L & $17 \%$ & $21 \%$ & $18 \%$ \\
\hline \multicolumn{6}{|l|}{ Microbes } \\
\hline E. coli & $3.5 \times 10^{3} \mathrm{MPN} / 100 \mathrm{~mL}$ & $12 \mathrm{MPN} / 100 \mathrm{~mL}$ & $2.5 \log s^{a}$ & 5.2 logs & 4.7 logs \\
\hline
\end{tabular}

a \% elimination or log inactivation limited by MRL. 
and wastewater treatment, a more comprehensive understanding of the available technologies in addition to tools that make them amenable to the current regulatory framework are required. Equipping utilities and operators with quick and simple proxies to assess oxidation and disinfection efficacy will reduce the analytical demand related to continuous monitoring of trace organic contaminants and microorganisms, allow for rapid adjustments to operational variables (e.g., ozone and/or $\mathrm{H}_{2} \mathrm{O}_{2}$ dose), and provide a basis for awarding removal credits for various contaminants.

This study provides quantitative information that can be used to tailor a surrogate framework for indicator compounds to an individual system, similar to what is now required by the California Department of Public Health. Differential $U_{254}$ absorbance and total fluorescence were correlated with trace organic contaminant oxidation and microbial inactivation to provide estimates of treatment efficacy in 17 different wastewater matrices from the U.S., Switzerland, and Australia. The results of this study indicate that $\Delta U_{254}$ and $\Delta \mathrm{TF}$ can be used as surrogates for target compound elimination. The primary benefit of this strategy is that it requires minimal equipment, expertise, time, and cost compared to full-scale monitoring of target compounds and pathogens. Automated online analyzers are available for UV absorbance and fluorescence so full-scale implementation of the empirical models developed in this study is entirely feasible. Although there is a certain amount of inherent variability in the models, the pilot- and full-scale validation efforts indicate that the models are robust. As mentioned earlier, similar models can be applied to other forms of advanced oxidation, such as $\mathrm{UV} / \mathrm{H}_{2} \mathrm{O}_{2}$, so expanded model databases are also warranted for other forms of treatment. Future research should also attempt to develop empirical models based on reaction rate constants with ozone and $\cdot \mathrm{OH}$.

With respect to microbial inactivation, the correlations may not yet be strong enough to warrant disinfection credits, particularly for microbes with significant lag phases (e.g., B. subtilis spores and Cryptosporidium oocysts), but the models still provide a useful estimate of expected log inactivation for some bacteria and viruses. Additional studies would be necessary to further refine the microbial inactivation models and integrate them into a regulatory framework.

\section{Acknowledgments}

The authors would like to thank members of the Applied Research and Development Center at the Southern Nevada Water Authority for all of their efforts during this study. The authors would also like to thank the technology partners, particularly APTwater, Hydranautics, s::can Messtechnik, and Wedeco/ITT, for their generous contributions to the project. The personnel at the various study sites were also instrumental in the design, scheduling, and implementation of the sampling efforts. This study was made possible through funding from the WateReuse Research Foundation (WRF-08-05, WRF-08-08, and WRF-09-10) and the Swiss Federal Office of the Environment. The comments and views detailed herein may not necessarily reflect the views of these funding agencies, their officers, directors, employees, affiliates or agents.

\section{Appendix A. Supplementary data}

Supplementary data related to this article can be found at http://dx.doi.org/10.1016/j.watres.2012.08.037.

\section{R E F E R E N C E S}

Acero, J.L., Stemmler, K., von Gunten, U., 2000. Degradation kinetics of atrazine and its degradation products with ozone and $\mathrm{OH}$ radicals: a predictive tool for drinking water treatment. Environmental Science and Technology 34, 591-597.

Adams, M., 1959. Bacteriophages. Book Bacteriophages. Interscience Publishers, New York.

Bahr, C., Schumacher, J., Ernst, M., Luck, F., Heinzman, B., Jekel, M., 2007. SUVA as control parameter for the effective ozonation of organic pollutants in secondary effluent. Water Science and Technology 55, 267-274.

Benner, J., Salhi, E., Ternes, T., von Gunten, U., 2008. Ozonation of reverse osmosis concentrate: kinetics and efficiency of beta blocker oxidation. Water Research 42, 3003-3012.

Bowman, R.H., Miller, P., Purchase, M., Schoellerman, R., 2001. Ozone-peroxide Advanced Oxidation Water Treatment System for Treatment of Chlorinated Solvents and 1,4dioxane. American Chemical Society National Meeting, San Diego, CA.

Buffle, M., Schumacher, J., Meylan, S., Jekel, M., von Gunten, U., 2006. Ozonation and advanced oxidation of wastewater: effect of $\mathrm{O}_{3}$ dose, $\mathrm{pH}, \mathrm{DOM}$ and HO• scavengers on ozone decomposion and HO• generation. Ozone Science \& Engineering 28, 247-259.

Burns, N., Hunter, G., Jackman, A., Hulsey, B., Coughenour, J., Walz, T., 2007. The return of ozone and the hydroxyl radical to wastewater disinfection. Ozone Science \& Engineering 29, 303-306.

Camacho-Munoz, D., Martin, J., Santos, J.L., Aparicio, I., Alonso, E., 2009. An affordable method for the simultaneous determination of the most studied pharmaceutical compounds as wastewater and surface water pollutants. Journal of Separation Science 32, 3064-3073.

CDPH, 2011. Groundwater Replenishment Reuse. Draft Regulations. Title 22 California Code of Regulations. California Department of Public Health.

Chen, W., Westerhoff, P., Leenheer, J.A., Booksh, K., 2003. Fluorescence excitation-emission matrix regional integration to quantify spectra for dissolved organic matter. Environmental Science and Technology 37, 5701-5710.

Deborde, M., Rabouan, S., Duguet, J., Legube, B., 2005. Kinetics of aqueous ozone-induced oxidation of some endocrine disruptors. Environmental Science and Technology 39, 6086-6092.

Dickenson, E.R.V., Drewes, J.E., Sedlak, D.L., Wert, E.C., Snyder, S.A., 2009. Applying surrogates and indicators to assess removal efficiency of trace organic chemicals during chemical oxidation of wastewaters. Environmental Science and Technology 43, 6242-6247.

Dodd, M.C., Buffle, M., von Gunten, U., 2006. Oxidation of antibacterial molecules by aqueous ozone: moiety-specific reaction kinetics and application to ozone-based wastewater treatment. Environmental Science and Technology 40, 1969-1977.

Dodd, M.C., Kohler, H.P.E., von Gunten, U., 2009. Oxidation of antibacterial compounds by ozone and hydroxyl radical: elimination of biological activity during aqueous ozonation 
processes. Environmental Science and Technology 43, 2498-2504.

Driedger, A., Staub, E., Pinkernell, U., Marinas, B., Koster, W., von Gunten, U., 2001. Inactivation of Bacillus subtilis spores and formation of bromate during ozonation. Water Research 35, 2950-2960.

Gerrity, D., Gamage, S., Holady, J.C., Mawhinney, D.B., Quinones, O., Trenholm, R.A., Snyder, S.A., 2011a. Pilot-scale evaluation of ozone and biological activated carbon for trace organic contaminant mitigation and disinfection. Water Research 45, 2155-2165.

Gerrity, D., Snyder, S., 2011. Review of ozone for water reuse applications: toxicity, regulations, and trace organic contaminant oxidation. Ozone Science \& Engineering 33, 253-266.

Gerrity, D., Stanford, B.D., Trenholm, R.A., Snyder, S.A., 2010. An evaluation of a pilot-scale nonthermal plasma advanced oxidation process for trace organic compound degradation. Water Research 44, 493-504.

Gerrity, D., Trenholm, R.A., Snyder, S.A., 2011b. Temporal variability of pharmaceuticals and illicit drugs in wastewater and the effects of a major sporting event. Water Research 45, 5399-5411.

Hoigne, J., Bader, H., 1994. Characterization of water quality criteria for ozonation processes. Part II: lifetime of added ozone. Ozone Science \& Engineering 16, 121-134.

Hollender, J., Zimmermann, S.G., Koepke, S., Krauss, M., McArdell, C.S., Ort, C., Singer, H., von Gunten, U., Siegrist, H., 2009. Elimination of organic micropollutants in a municipal wastewater treatment plant upgraded with a full-scale postozonation followed by sand filtration. Environmental Science and Technology 43, 7862-7869.

Huber, M.M., Canonica, S., Park, G.Y., von Gunten, U., 2003. Oxidation of pharmaceuticals during ozonation and advanced oxidation processes. Environmental Science and Technology 37, 1016-1024.

Huber, M.M., Gobel, A., Joss, A., Hermann, N., Loffler, D., McArdell, C.S., Ried, A., Siegrist, H., Ternes, T.A., von Gunten, U., 2005. Oxidation of pharmaceuticals during ozonation of municipal wastewater effluents: a pilot study. Environmental Science and Technology 39, 4290-4299.

Huber, M.M., Ternes, T.A., von Gunten, U., 2004. Removal of estrogenic activity and formation of oxidation products during ozonation of $17 \alpha$-ethinylestradiol. Environmental Science and Technology 38, 5177-5186.

Kaiser, H.P., Koster, O., Gresch, M., Perissef, P. Jaggi, P., Salhi, E., von Gunten, U. Process control of ozonation systems: a novel real-time approach. Ozone: Science and Engineering, submitted for publication.

Katsoyiannis, I.A., Canonica, S., von Gunten, U., 2011. Efficiency and energy requirements for the transformation of organic micropollutants by ozone, ozone $/ \mathrm{H}_{2} \mathrm{O}_{2}$ and $\mathrm{UV} / \mathrm{H}_{2} \mathrm{O}_{2}$. Water Research 45, 3811-3822.

Lee, Y., Escher, B.I., von Gunten, U., 2008. Efficient removal of estrogenic activity during oxidative treatment of waters containing steroid estrogens. Environmental Science and Technology 42, 6333-6339.

Lee, Y., von Gunten, U., 2012. Quantitative Structure-Activity Relationships (QSARs) for the transformation of organic micropollutants during oxidative water treatment. Water Research 46, 6177-6195.

Mesquita, M.M.F., Stimson, J., Chae, G.-T., Tufenkji, N., Ptzcek, C.J., Blowes, D.W., Emelko, M.B., 2010. Optimal preparation and purification of PRD1-like bacteriophages for use in environmental fate and transport studies. Water Research 44, 1114-1125.
Nanaboina, V., Korshin, G.V., 2010. Evolution of absorbance spectra of ozonated wastewater and its relationship with the degradation of trace-level organic species. Environmental Science and Technology 44, 6130-6137.

Packer, J.L., Werner, J.J., Latch, D.E., McNeill, K., Arnold, W.A., 2003. Photochemical fate of pharmaceuticals in the environment: Naproxen, diclofenac, clofibric acid, and ibuprofen. Aquatic Science 65, 342-351.

Pisarenko, A.N., Stanford, B.D., Yan, D., Gerrity, D., Snyder, S.A., 2012. Effects of ozone and ozone/peroxide on trace organic contaminants and NDMA in drinking water and water reuse applications. Water Research 46, 316-326.

Razavi, B., Song, W., Cooper, W.J., Greaves, J., Jeong, J., 2009. Freeradical-induced oxidative and reductive degradation of fibrate pharmaceuticals: kinetic studies and degradation mechanisms. The Journal of Physical Chemistry A 113, 1287-1294.

Real, F.J., Javier Benitez, F., Acero, J.L., Sagasti, J.J.P., Casas, F., 2009. Kinetics of the chemical oxidation of the pharmaceuticals primidone, ketoprofen, and diatrizoate in ultrapure and natural waters. Industrial and Engineering Chemistry Research 48, 3380-3388.

Reungoat, J., Escher, B.I., Macova, M., Argaud, F.X., Gernjak, W., Keller, J., 2012. Ozonation and biological activated carbon filtration of wastewater treatment plant effluents. Water Research 46, 863-872.

Reungoat, J., Macova, M., Escher, B.I., Carswell, S., Mueller, J.F., Keller, J., 2010. Removal of micropollutants and reduction of biological activity in a full scale reclamation plant using ozonation and activated carbon filtration. Water Research 44, 625-637.

Rosario-Ortiz, F.L., Wert, E.C., Snyder, S.A., 2010. Evaluation of $\mathrm{UV} / \mathrm{H}_{2} \mathrm{O}_{2}$ treatment for the oxidation of pharmaceuticals in wastewater. Water Research 44, 1440-1448.

Rosenfeldt, E.J., Linden, K.G., 2004. Degradation of endocrine disrupting chemicals bisphenol A, ethinyl estradiol, and estradiol during UV photolysis and advanced oxidation processes. Environmental Science and Technology 38, $5476-5483$

Song, W., Cooper, W.J., Peake, B.M., Mezyk, S.P., Nickelsen, M.G., O'Shea, K.E., 2009. Free-radical induced oxidative and reductive degradation of $\mathrm{N}, \mathrm{N}$-diethyl-meta-toluamide (DEET): kinetic studies and degradation pathways. Water Research 43 635-642.

Stalter, D., Magdeburg, A., Oehlmann, J., 2010a. Comparative toxicity assessment of ozone and activated carbon treated sewage effluents using an in vivo test battery. Water Research 44, 2610-2620.

Stalter, D., Magdeburg, A., Weil, M., Knacker, T., Oehlmann, J., $2010 b$. Toxication or detoxication? In vivo toxicity assessment of ozonation as advanced wastewater treatment with the rainbow trout. Water Research 44, 439-448.

Suarez, S., Dodd, M.C., Omil, F., von Gunten, U., 2007. Kinetics of triclosan oxidation by aqueous ozone and consequent loss of antibacterial activity: relevance to municipal wastewater ozonation. Water Research 41, 2481-2490.

Thurston-Enriquez, J.A., Haas, C.N., Jacangelo, J., Riley, K., Gerba, C.P., 2003. Inactivation of feline calicivirus and adenovirus type- 40 by UV radiation. Applied and Environmental Microbiology 69, 577-582.

Trenholm, R.A., Vanderford, B.J., Snyder, S.A., 2009. On-line solid phase extraction LC-MS/MS analysis of pharmaceutical indicators in water: a green alternative to conventional methods. Talanta 79, 1425-1432.

Vanderford, B.J., Rosario-Ortiz, F.L., Snyder, S.A., 2007. Analysis of p-chlorobenzoic acid in water by liquid chromatographytandem mass spectrometry. Journal of Chromatography 1164, 219-223. 
von Sonntag, C., von Gunten, U., 2012. Chemistry of ozone in water and wastewater treatment: From basic principles to applications. IWA Publishing, London.

Watts, M.J., Linden, K.G., 2009. Advanced oxidation kinetics of aqueous trialkyl phosphate flame retardants and plasticizers. Environmental Science and Technology 43, 2937-2942.

Wert, E.C., Rosario-Ortiz, F.L., Snyder, S.A., 2009a. Effect of ozone exposure on the oxidation of trace organic contaminants in wastewater. Water Research 43, 1005-1014.

Wert, E.C., Rosario-Ortiz, F.L., Snyder, S.A., 2009b. Using ultraviolet absorbance and color to assess pharmaceutical oxidation during ozonation of wastewater. Environmental Science and Technology 43, 4858-4863.

Yuan, F., Hu, C., Hu, X., Qu, J., Yang, M., 2009. Degradation of selected pharmaceuticals in aqueous solution with UV and $\mathrm{UV} / \mathrm{H}_{2} \mathrm{O}_{2}$. Water Research 43, 1766-1774.

Zimmermann, S.G., Wittenwiler, M., Hollender, J., Krauss, M., Ort, C., Siegrist, H., von Gunten, U., 2011. Kinetic assessment and modeling of an ozonation step for fullscale municipal wastewater treatment: micropollutant oxidation, by-product formation and disinfection. Water Research 45, 605-617. 